\title{
Temporal/Spatial Variation of Terrestrial Water Storage and Groundwater Storage in Typical Inland River Basins of Central Asia
}

\author{
Ye Lyu ${ }^{1,2,3}$, Yue Huang ${ }^{1,2,4,5, *}$, Anming Bao ${ }^{1,2,5}$, Ruisen Zhong ${ }^{1,2,4}$ and Han Yang ${ }^{3}$ \\ 1 State Key Laboratory of Desert and Oasis Ecology, Xinjiang Institute of Ecology and Geography, \\ Chinese Academy of Sciences, Urumqi 830011, China; lyu.y@139.com (Y.L.); baoam@ms.xjb.ac.cn (A.B.); \\ zhongrs@ms.xjb.ac.cn (R.Z.) \\ 2 Key Laboratory of GIS \& RS Application, Xinjiang Uygur Autonomous Region, Urumqi 830011, China \\ 3 School of Geography Sciences and Tourism, Xinjiang Normal University, Urumqi 830054, China; \\ yanghan_89@sina.com \\ 4 Research Center for Ecology and Environment of Central Asia, Chinese Academy of Sciences, \\ Urumqi 830011, China \\ 5 China-Pakistan Joint Research Center on Earth Sciences, CAS-HEC, Islamabad 45320, Pakistan \\ * Correspondence: huangy@ms.xjb.ac.cn; Tel.: +86-0991-782-3131
}

Citation: Lyu, Y.; Huang, Y.; Bao, A.; Zhong, R.; Yang, H. Temporal/Spatial Variation of Terrestrial Water Storage and Groundwater Storage in Typical Inland River Basins of Central Asia. Water 2021, 13, 3385. https:// doi.org/10.3390/w13233385

Academic Editor:

Adriana Bruggeman

Received: 22 September 2021

Accepted: 22 November 2021

Published: 1 December 2021

Publisher's Note: MDPI stays neutral with regard to jurisdictional claims in published maps and institutional affiliations.

Copyright: () 2021 by the authors. Licensee MDPI, Basel, Switzerland. This article is an open access article distributed under the terms and conditions of the Creative Commons Attribution (CC BY) license (https:// creativecommons.org/licenses/by/ $4.0 /)$.

\begin{abstract}
In this study, the Amu Darya river basin, Syr Darya river basin and Balkhash lake basin in Central Asia were selected as typical study areas. Temporal/spatial changes from 2002 to 2016 in the terrestrial water storage (TWS) and the groundwater storage (GWS) were analyzed, based on RL06 Mascon data from the Gravity Recovery and Climate Experiment (GRACE) satellite, and the sum of soil water content, snow water equivalent and canopy water data that were obtained from Global Land Data Assimilation System (GLDAS). Combing meteorological data and land use and cover change (LUCC) data, the joint impact of both human activities and climate change on the terrestrial water storage change (TWSC) and the groundwater storage change (GWSC) was evaluated by statistical analysis. The results revealed three findings: (1) The TWS retrieved by CSR (Center for Space Research) and the JPL (Jet Propulsion Laboratory) showed a decreasing trend in the three basins, and the variation of TWS showed a maximum surplus in spring (March-May) and a maximum deficit in autumn (September-November). (2) The decreasing rates of groundwater storage that were extracted, based on JPL and CSR Mascon data sets, were $-2.17 \mathrm{~mm} /$ year and $-3.90 \mathrm{~mm} /$ year, $-3.72 \mathrm{~mm} /$ year and $-4.96 \mathrm{~mm} /$ year, $-1.74 \mathrm{~mm} /$ year and $-3.36 \mathrm{~mm} /$ year in the Amu Darya river basin, Syr Darya river basin and Balkhash lake basin, respectively. (3) In the Amu Darya river basin, annual precipitation showed a decreasing trend, while the evapotranspiration rate showed an increasing trend due to an increasing temperature, and the TWS decreased from 2002 to 2016 in most areas of the basin. However, in the middle reaches of the Amu Darya river basin, the TWS increased due to the increase in cultivated land area, water income from flooded irrigation, and reservoir impoundment. In the upper reaches of the Syr Darya river basin, the increase in precipitation in alpine areas leads to an increase in glacier and snow meltwater, which is the reason for the increase in the TWS. In the middle and lower reaches of the Syr Darya river basin, the amount of evapotranspiration dissipation exceeds the amount of water replenished by agricultural irrigation, which leads to a decrease in TWS and GWS. The increase in precipitation in the northwest of the Balkhash lake basin, the increase in farmland irrigation water, and the topography (higher in the southeast and lower in the northwest) led to an increase in TWS and GWS in the northwest of the Balkhash lake basin. This study can provide useful information for water resources management in the inland river basins of Central Asia.
\end{abstract}

Keywords: GRACE; terrestrial water storage; groundwater storage; climate change 


\section{Introduction}

Inland river (lake) basins are typical water resource utilization units in Central Asia. The mountainous areas in the east of Central Asia have more precipitation, and the water is preserved in the form of glaciers and permanent snow cover. The meltwater from glaciers and snow is the main supply for rivers and lakes [1,2]. The river network in plains, deserts and lowlands is sparse; these regions, with more human activity, have become the main dissipation area of water resources in Central Asia [3]. Because of the special geographical location of the inland river basin, the precipitation in the area is scarce, evaporation is significant, the river runoff is reduced, and the lake shrinks, leading to a scarcity of water resources [4]. In the past 60 years, the utilization of water resources in Central Asian countries has experienced a process from integration to division. After the 1990s, due to the change in social patterns in Central Asia, the original water resource management system disintegrated, and climate change in recent years has made the water resource problem among the relevant countries worse; the conflict between water demands from agricultural development and ecological environment protection has become increasingly prominent [5]. An in-depth understanding of the mode of formation and exchange process of water resources in Central Asia, and the exploration of regional water resource storage and its temporal and spatial variations, can provide scientific support for alleviating the water resource problems in inland river basins stressed under the dual influences of climate change and human activities [6].

Traditional methods of water resource change monitoring are mostly based on meteorological and hydrological observation data. Under the conditions of few observation stations and discontinuous observation in the inland river basins, it is difficult to accurately evaluate the temporal and spatial changes of regional water resource storage. The development of remote-sensing technology provides a new way of observation of the water cycle [7-9]. In 2002, the Gravity Recovery and Climate Experiment (GRACE) satellites proved effective for tracking the inversion of water storage change, which is highly useful in Central Asia where traditional monitoring data are lacking. In addition, when integrated with data on the soil water content (SW), snow water equivalent (SW) and canopy water $(\mathrm{CW})$, which were obtained from the Global Land Data Assimilation System (GLDAS), the groundwater storage (GWS) change could be evaluated using the water balance model [10]. Previously, several researchers have carried out studies on terrestrial water storage change (TWSC) in Central Asia, based on the GRACE data. For example, Yang et al. [11] and Zhang et al. [12] investigated the TWSC in the Tianshan mountain area from 2003 to 2014, using the GRACE satellite data; it was found that terrestrial water storage (TWS) increased in the western Tianshan mountain and decreased in the eastern and middle portions. Hu et al. [13] analyzed the variation of TWS and its influencing factors under changing environments and indicated that the regional economy and ecological environment are highly affected by TWSC in Central Asian countries. Deng et al. [14] analyzed the influence of climate change on TWS in Central Asia over the past decade and indicated that TWS experienced a decreasing trend in Central Asia from 2003 to 2013, human activities being the dominant factor driving the decline of TWS in the Aral Sea region and the northern Tarim River Basin. Hu et al. [15] found that the TWSC positively correlates with the level of precipitation, and negatively correlates, allowing for a three-month lag, with temperature and potential evapotranspiration (PET). Yang et al. [16] indicated that the decrease in TWS, the occurrence of drought events, the decrease in precipitation, the increase in evaporation and other problems exacerbate the shortage of water resources, leading to an increase in the pressure on groundwater resources. Central Asia covers a vast area and is composed of many inland river (lake) basins. Climate change affects the formation and storage of water resources in mountainous areas; it also intensifies the dissipation process of water resources in oases and deserts. In addition, with the deepening impact of human activities, the changes and spatial-temporal heterogeneity of water storage in the inland river basin of Central Asia are significant, which intensifies the shortage of water resources at the regional and basin levels. However, most of the previous studies have been carried out on 
a regional scale to explore the changes and influencing factors of TWS. Zmijewski et al. [17], estimating the effects of anthropogenic modification on water balance in the Aral Sea Basin using the GRACE data, indicated that the mass loss throughout the basin is most likely attributable to increased evapotranspiration, due to the area's inefficient irrigation systems. There are few studies focused on the comparison of TWSC and GWSC and their driving mechanism on the basin scale.

Therefore, the objectives of this study are to (i) extract data for the TWSC and GWSC series in three typical inland river basins in Central Asia, using RL06 Mascon data and the GLDAS hydrological model; (ii) analyze the spatial-temporal variation of terrestrial and groundwater storage and investigate the heterogeneity of TWSC and GWSC among different basins; (iii) quantitatively analyze the impact of climate and human activities on water resources. The results can provide a basis for water resource management and ecological protection in the inland river (lake) basins of Central Asia.

\section{Materials and Methods}

\subsection{Study Area}

Central Asia is located in the hinterland of the Eurasian continent, far from the sea, with a shortage of water resources, an arid climate and a fragile desert ecosystem. It is a typical temperate arid desert area. Considering the spatiotemporal heterogeneity of water resource problems in each inland river basin and the driving factors causing changes in water storage among different basins, the Amu Darya river basin, Syr Darya river basin and Balkhash lake basin, which are typical inland river (lake) basins distributed throughout Central Asia, were selected as the study areas (Figure 1).

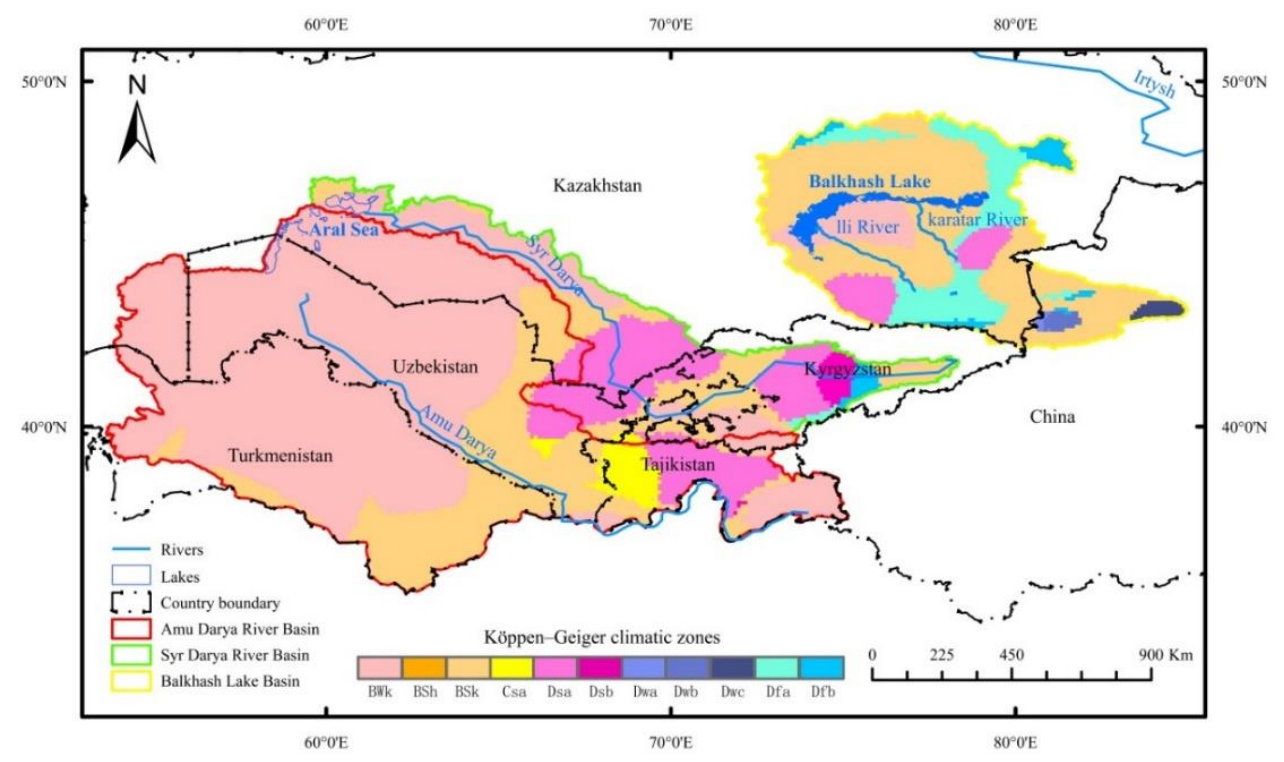

Figure 1. Location of the study area.

The Amu Darya river basin is located at $34^{\circ} 30^{\prime} \sim 43^{\circ} 45^{\prime} \mathrm{N}$ and $58^{\circ} 15^{\prime} \sim 75^{\circ} 07^{\prime} \mathrm{E}$, with a total area of about 1.08 million $\mathrm{km}^{2}$. The upper reaches of the basin are dominated by tall east-west mountains, while the lower reaches are mostly flat desert oases and are the main areas for human activities, with a huge consumption of water resources and relatively low incoming water $[18,19]$. The Amu Darya river basin has a typical temperate continental climate, cold in winter, hot in summer, with relatively low humidity. Annual precipitation in the upper reaches of the basin is more than $1000 \mathrm{~mm}$, while the precipitation in the foothills and plains of the lower reaches is less than $100 \mathrm{~mm}$; the average temperature in July is $26-30^{\circ} \mathrm{C}$, and the temperature in January can drop below $-30^{\circ} \mathrm{C}$ [20].

The Syr Darya river basin is located at $34^{\circ} 30^{\prime} \sim 43^{\circ} 45^{\prime} \mathrm{N}$ and $58^{\circ} 15^{\prime} \sim 75^{\circ} 07^{\prime} \mathrm{E}$, with a total area of about 0.32 million $\mathrm{km}^{2}$. The average temperature in the basin is about $14.2^{\circ} \mathrm{C}$, 
the annual precipitation is $60-502 \mathrm{~mm}$ in the low-altitude areas, and the evapotranspiration is between 1150 and $1420 \mathrm{~mm}$ [21].

The Balkhash lake basin is located between $42.21^{\circ} \sim 49.14^{\circ} \mathrm{N}$ and $72.47^{\circ} \sim 85.02^{\circ} \mathrm{E}$, with a total area of about 0.42 million $\mathrm{km}^{2}$, of which $86.4 \%$ is located in Kazakhstan [22-24]. The basin rises gradually from northwest to southeast, and the runoff is mainly from alpine glacier meltwater and a small amount of rainfall. The water vapor carried by the westerly circulation is blocked by the Tianshan Mountains, which results in abundant precipitation in the southeast of the basin. The average annual precipitation in the valley is about $300 \mathrm{~mm}$, and the average annual precipitation in the mountain area is about $500 \sim 1000 \mathrm{~mm}$. The water dissipation area is in the central and western parts of the basin and the central belt in the northwest is in the Balkhash Lake district, which is also the main agricultural irrigation area in Kazakhstan [25].

According to the world map of Koppen-Geiger climate zones, the study area covers 11 climate zones, which include the BWk (arid, desert, cold arid), BSh (arid, steppe, hot arid), BSk (arid, steppe, cold arid), Csa (warm temperate, summer dry, hot summer), Dsa (snow, summer dry, hot summer), Dsb (snow, summer dry, warm summer), Dwa (snow, winter dry, hot summer), Dwb (snow, winter dry, warm summer), Dwc (snow, winter dry, cool summer), Dfa (snow, fully humid, hot summer), and Dfb (snow, fully humid, warm summer).

\subsection{Dataset}

GRACE gravity satellite data can invert the changes in terrestrial water storage (TWSC). The data products have been developed to the sixth generation (RL06) and were published by the University of Texas at Austin Center for Space Research (CSR), Jet Propulsion Laboratory (JPL) and the German Research Center for Geosciences (GFZ). In this study, the RL06 Mascon monthly data products provided by the CSR and the JPL were used; this can improve the SNR of inversion results, reduce stripe errors and retain more effective signals with higher spatial resolution. The JPL and CSR Mascon solutions deal with C20 (degree 2 order 0 ) and the degree -1 coefficients (Geocenter) similarly. Different glacial isostatic adjustment corrections have been applied; the JPL Mascon is based on the ICE6G-D model, and the CSR Mascon is based on the model by Wahr et al. [26]. The RL06 CSR Mascon data (http:/ / www2.csr.utexas.edu/grace/RL06.html (accessed on 23 November 2021)) and RL06 JPL Mascon data (https: / / grace.jpl.nasa.gov / data / getdata/jpl_global_mascons / (accessed on 23 November 2021)) span 180 months from January 2002 to December 2016, and the missing months are replaced by linear interpolation.

GLDAS is a high-temporal-resolution assimilation-system model that can provide realtime information on land surface changes. The main hydrological models include Mosaic, Noah, the Community Land Model (CLM), and Variable Infiltration Capacity (VIC) models. In the current paper, monthly soil moisture content, snow water equivalent, canopy water storage and evapotranspiration data from January 2002 to December 2016 with $1^{\circ} \times 1^{\circ}$ resolution were provided by the Noah model via GLDAS (https://disc.gsfc.nasa.gov/ (accessed on 23 November 2021)).

The monthly precipitation and temperature data used in this paper were obtained from the CRU TS4.04 dataset, which was released by the Climate Research Unit of East Anglia $(\mathrm{CRU})$ in the UK. The spatial resolution of the data is $0.5^{\circ} \times 0.5^{\circ}$ and covers all the land areas of the world (excluding the Antarctic) (http://data.ceda.ac.uk/badc/cru/data/cru_ts/ (accessed on 23 November 2021)).

Land use and land cover (LULC) data were collected from the Earth System Science Data Sharing Platform-Xinjiang and Central Asia Scientific Data Sharing Platform and were released by the Chinese Academy of Sciences (CAS). Land-use maps in 2000 and 2015, with a spatial resolution of $30 \mathrm{~m}$, were used for evaluating the land use and land cover changes in typical river basins. 


\subsection{Methods}

\subsubsection{Inversion of TWSC by the GRACE Time-Varying Gravity Field}

The Mascon method directly calculates the equivalent water height corresponding to the mass change in a certain region, mainly through the high-precision inter-satellite observation data of the GRACE satellites. Its remarkable feature is that the earth mass change is directly calculated as a parameter, and thus it is more flexible with respect to the region of interest [27]. Watkins et al. [28] designated 4551 spherical caps of equal area with uniform mass distribution (Mascon) on a global scale and obtained the equivalent water column height value of each ball cap through the weighted least squares method, using JPL gravity field data. In this study, each parameter corresponds to the loss or surplus of terrestrial water storage in a specific time period and in a specific area. GRACE satellite time-varying gravity field model data were output into longitude and latitude network node data, and the ArcGIS platform was used for regional statistical analysis [29].

\subsubsection{Estimation of the GWSC}

The terrestrial water balance approach is used to obtain the groundwater storage level. The sources of storage change from GLDAS are equated to GRACE total water storage change [30]. GRACE gravity satellite data inversion represents the change in land total water storage, including the snow water equivalent, vegetation canopy water storage, soil water storage and underground water storage [31], while the GLDAS hydrological model can simulate soil water content, canopy water content and snow water equivalent. Therefore, the formula of groundwater storage change is as follows:

$$
\Delta W_{g w}=\Delta W_{\text {grace }}-\Delta W_{\text {swe }}-\Delta W_{c a n}-\Delta W_{s m}
$$

where $\Delta W_{\text {grace }}$ is the change in total water storage established by GRACE, $\Delta W_{g w}$ is the change in groundwater storage, $\Delta W_{\text {swe }}$ is the snow depth water equivalent storage change, $\Delta W_{c a n}$ is the change in canopy water storage and $\Delta W_{s m}$ is the change in soil moisture content.

\subsubsection{Raster-Based Spatial Trend Analysis}

The inter-annual variation trends of precipitation, surface temperature and water storage from 2002 to 2016 were analyzed. Taking the annual and monthly parameters of each hydrological factor study area as input variables, the long time-series data of each parameter were fitted using the least-squares method, and the inter-annual variation and inter-annual variation rates of the slope characteristic parameter of the fitting regression line were obtained. When the slope is positive, this indicates that the parameter is increasing, and vice versa. The formula for calculating the change rate is as follows:

$$
\text { slope }=\frac{\sum_{i=1}^{n} x_{i} t_{i}-\frac{1}{n}\left(\sum_{i=1}^{n} x_{i}\right)\left(\sum_{i=1}^{n} t_{i}\right)}{\sum_{i=1}^{n} t_{i}{ }^{2}-\frac{1}{n}\left(\sum_{i=1}^{n} t_{i}\right)^{2}}
$$

where slope represents the linear fitting slope, $x_{i}$ is the parameter of year $i, t$ is the year, and $n$ is the total number of years. When slope $>0$, this shows that the value of the evaluation parameter increases with time; that is, the evaluation factor has an increasing trend. Conversely, when the slope $<0$, this indicates that the evaluation parameters show a downward trend with the change in time.

\subsubsection{Spatial Correlation Analysis}

The spatial correlation analysis method, based on a grid, was used to study the relationship between changes in terrestrial water storage and precipitation and soil moisture content. The correlation coefficients between terrestrial water storage, groundwater storage, precipitation, surface temperature and other hydrological factors were calculated pixel by pixel to characterize the correlation between terrestrial water storage and other 
hydrological factors. The correlation coefficient $r_{x y}$ of the original sample can be calculated in this way, with $n$ used with $x$ and $y$ for the observations $x_{1}, x_{2}, L, x_{n}$ and $y_{1}, y_{2}, L, y_{n}$ :

$$
r_{x y}=\frac{\sum_{i=1}^{n}\left[\left(x_{i}-\bar{x}\right)\left(y_{i}-\bar{y}\right)\right]}{\sqrt{\sum_{i=1}^{n}\left(x_{i}-\bar{x}\right)^{2} \sum_{i=1}^{n}\left(y_{i}-\bar{y}\right)^{2}}}
$$

In this equation, $n$ is the number of samples, $\bar{x}$ is the mean of the variable $x$, and $\bar{y}$ is the mean of the variable $y$. When $r_{x y}$ is positive, $x$ is positively correlated with $y$; when $r_{x y}$ is negative, $x$ is negatively correlated with $y$. If $r_{x y}= \pm 1$, this means that there is a one-to-one relationship between $x$ and $y$. Thus, the bigger $r_{x y}$ is, the closer $x$ is to $y$.

\subsubsection{Mann-Kendall Trend Test}

The Mann-Kendall test is non-parametric and is also known as a no-distribution test. Its advantage lies in the fact that it does not need to follow a certain distribution and is not affected by a few outliers. This makes it suitable for sequential variables, is easy to calculate and is widely used [32,33]. This study tests the significance of a long time series of terrestrial water and groundwater storage data, precipitation, temperature and other climatic factors. This method was first proposed by Mann, then improved by Kendall in 1975, and is thus known as the Mann-Kendall method. It can be summarized as follows:

For time series $\mathrm{X}$ with multiple sample sizes, the standardized test statistics are as follows:

$$
Z= \begin{cases}\frac{S-1}{\sqrt{\operatorname{Var}(S)}} & (S<0) \\ 0 & (S=0) \\ \frac{S+1}{\sqrt{\operatorname{Var}(S)}} & (S<0)\end{cases}
$$

Then:

$$
\begin{array}{r}
\mathrm{S}=\sum_{i=1}^{n-1} \sum_{j=i+1}^{n} \operatorname{sgn}\left(x_{j}-x_{i}\right) \\
\operatorname{sgn}= \begin{cases}1 & \left(x_{j}-x_{i}>0\right) \\
0 & \left(x_{j}-x_{i}=0\right) \\
-1 & \left(x_{j}-x_{i}<0\right)\end{cases} \\
\operatorname{Var}_{(S)}=\frac{n(n-1)(2 n+5)}{18}
\end{array}
$$

In this formula, $x_{i}$ and $x_{j}$ represent pixel values at the moments of pixel $i$ and $j, n$ represents the length of the time series, sgn is a sign function, and the value range of statistic $Z$ is $(-\infty,+\infty)$. In determining the level of significance of $\alpha$, if $|Z|>U_{1-\frac{\alpha}{2}}$, this indicates that there is a significant trend change in the sequence; otherwise, there is no significant trend change. In general, the value of $\alpha$ is 0.01 or 0.05 , which indicates whether the trend of change in the time series of the elements is significant, at a confidence level of 0.01 or 0.05 .

The research process is shown in Figure 2. The TWSC was extracted from GRACE data, and the GWSC was calculated using the water balance equation, combined with the GLDAS-Noah data. The spatial correlation analysis method and the Mann-Kendall test were used to analyze the spatial-temporal variation of the TWS and GWS, then the impacts of human activities and climate changes on the TWSC and GWSC in typical inland lake basins were evaluated by integrating the meteorological, LUCC and evapotranspiration data. 


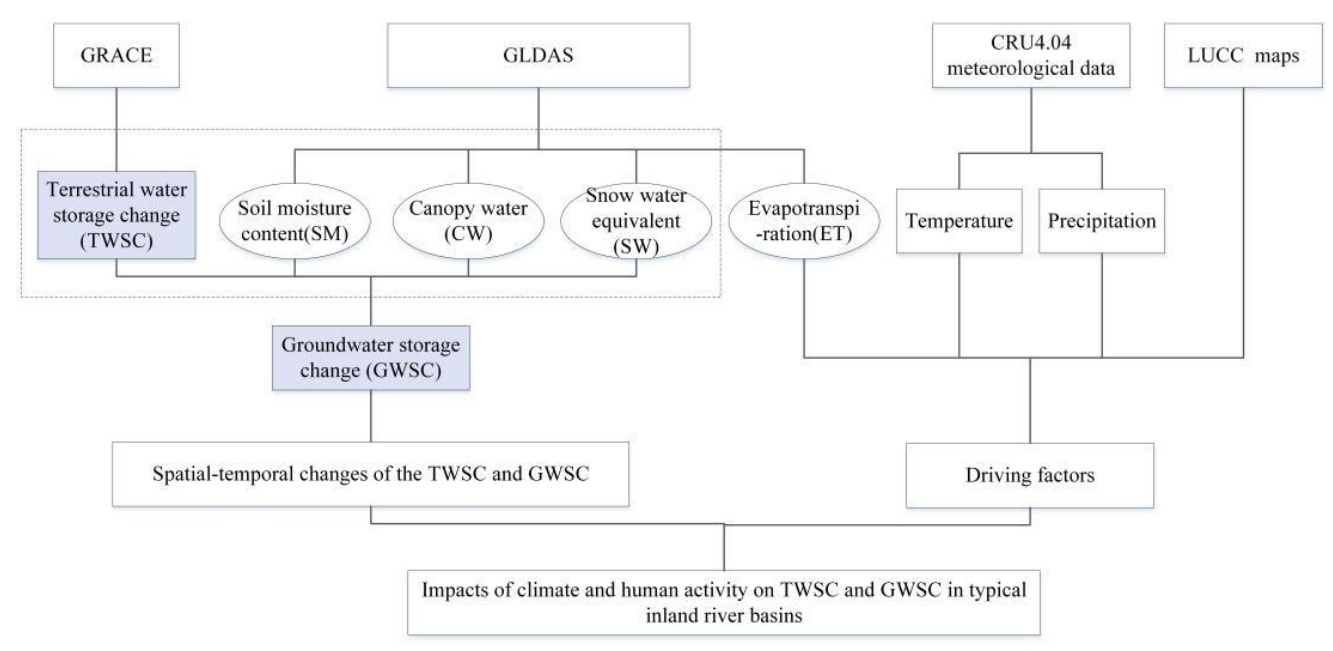

Figure 2. Research formwork of this study.

\section{Results}

\subsection{Spatiotemporal Variation of the TWSC}

\subsubsection{Comparison of TWSC Derived from GRACE and GLDAS-Noah}

It is necessary to verify the accuracy of results after obtaining TWSC based on GRACE; thus, the GLDAS hydrological model is used for GRACE verification [34]. By comparing the two time series in Figure 3, it can be seen that seasonal variation is obvious in the time variation of terrestrial storage, as estimated by GRACE and GLDAS. The TWS derived from GLDAS-Noah decreased at a rate of $-0.71 \mathrm{~mm} /$ year and $-1.41 \mathrm{~mm} /$ year $(p<0.05)$ in the Amu Darya river basin and the Syr Darya river basin, respectively, which was consistent with the downward trend of GRACE inversion, but the decrease is smaller than that of the GRACE inversion (Figure 3a,b). However, the TWS in the Balkhash lake basin, inverted by GRACE, decreased at a rate of $-5.23 \mathrm{~mm} /$ year and $-0.60 \mathrm{~mm} /$ year, and the inversion results of GLDAS increased at a rate of $1.13 \mathrm{~mm} /$ year (Figure 3c).
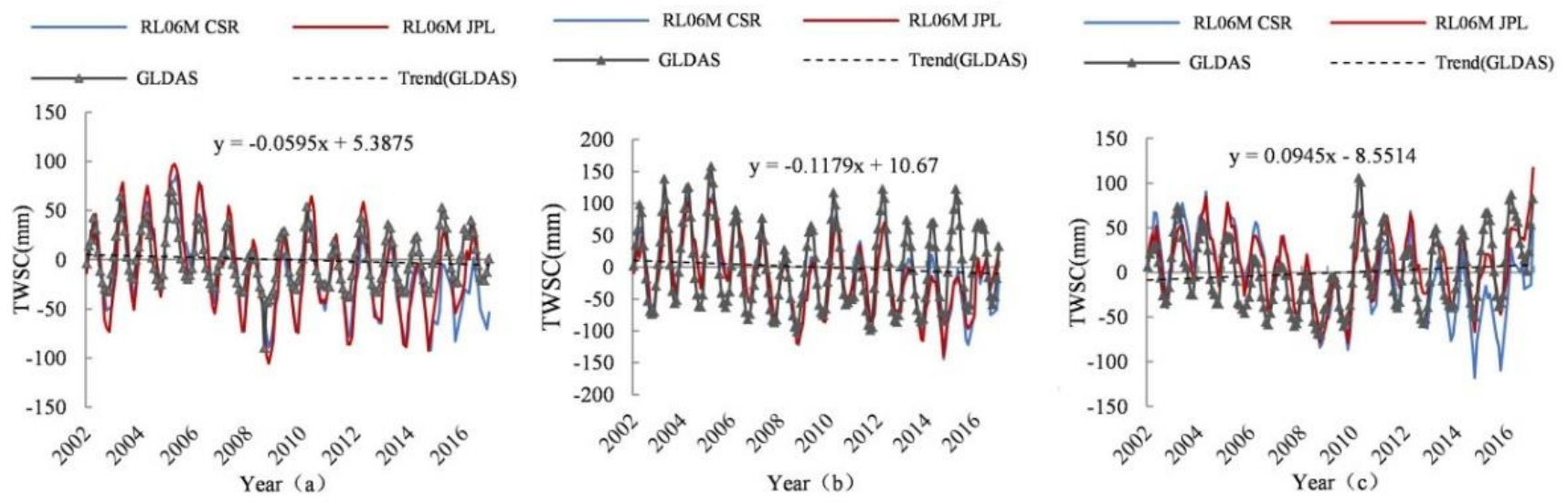

Figure 3. Comparative analysis of the TWSC retrieved by GRACE and GLDAS in (a) the Amu Darya river basin, (b) the Syr Darya river basin and (c) the Balkhash lake basin.

In order to better display the relationship between the terrestrial water storage retrieved by GRACE and the GLDAS hydrological model, four evaluation metrics were used to describe the properties of error in GRACE and GLDAS. These are the correlation coefficient (CC), mean relative error (MRE), centered relative root-mean-square error (CRMSE) and the Kling-Gupta efficiency coefficient (KGE), used to compare the two sets of values $[35,36]$. The results are shown in Table 1 . CC between the TWSC derived from GRACE and the GLDAS-Noah hydrological model ranged from 0.6 to 0.8 , indicating a significant, good correlation. The MRE of the RL06M-CSR was smaller than that of the RL06-JPL in the 
Balkhash lake basin, while in the Amu Darya river basin and the Syr Darya river basin, the MRE of the RL06M-CSR and RL06-JPL were similar. The CRMSE of RL06M-CSR was much higher than that of the RL06M-JPL in the Balkhash lake basin and showed similar values in the Amu Darya river basin and the Syr Darya river basin. The highest values of KGE were found in the Balkhash lake basin, and both KGEs of RL06M-CSR and RL06M-JPL were higher than 0.80 .

Table 1. Correlation coefficient (CC), mean relative error (MRE), centered relative root-mean-square error (CRMSE) and Kling-Gupta efficiency coefficient (KGE) of the terrestrial water storage change (TWSC) derived from GRACE CSR and JPL, versus the TWSC of GLDAS in three river basins from 2002 to 2016.

\begin{tabular}{ccccc}
\hline \multirow{2}{*}{ Metrics } & GRACE & $\begin{array}{c}\text { Amu Darya } \\
\text { River Basin }\end{array}$ & $\begin{array}{c}\text { GLDAS-NOAH } \\
\text { Syr Darya River } \\
\text { Basin }\end{array}$ & $\begin{array}{c}\text { Balkhash Lake } \\
\text { Basin }\end{array}$ \\
\hline \multirow{2}{*}{ CC } & RL06M-CSR & $0.75^{* *}$ & $0.80^{* *}$ & $0.63^{* *}$ \\
& RL06M-JPL & $0.82^{* *}$ & $0.77^{* *}$ & $0.79 *$ \\
\hline \multirow{2}{*}{ MRE } & RL06M-CSR & 1.07 & 0.57 & 0.14 \\
& RL06M-JPL & 1.06 & 0.62 & 0.67 \\
\hline \multirow{2}{*}{ CRMSE } & RL06M-CSR & 0.79 & 0.48 & 1.86 \\
& RL06M-JPL & 0.70 & 0.49 & 0.44 \\
\hline \multirow{2}{*}{ KGE } & RL06M-CSR & 0.45 & 0.69 & 0.59 \\
& RL06M-JPL & 0.32 & 0.66 & 0.84 \\
\hline \multirow{2}{*}{ *-at the level of 0.01 (double-tailed) the correlation was significant. }
\end{tabular}

\subsubsection{Time Variation of the TWSC}

Figure $4 \mathrm{a}-\mathrm{c}$ shows the interannual trend of terrestrial water storage changes in the study area. Both of the two data products reflect the finding that the three basins all show a consistent downward trend in terrestrial water storage, but the decline in CSR-M was greater than that of JPL-M, and the difference was most obvious in the Balkhash lake basin. The loss rate of terrestrial water storage in the Amu Darya river basin from 2002 to 2016, as calculated by CSR-M and JPL-M, was $-4.66 \mathrm{~mm} /$ year and $-2.88 \mathrm{~mm} /$ year, respectively $(p<0.05)$. In the Syr Darya river basin, the change rates of terrestrial water storage from 2002 to 2016, calculated by CSR-M and JPL-M data products, were $-6.10 \mathrm{~mm} /$ year and $-5.13 \mathrm{~mm} /$ year, respectively $(p<0.01)$. The change rates calculated by the two for the Balkhash lake basin were $-5.23 \mathrm{~mm} /$ year and $-0.60 \mathrm{~mm} /$ year, respectively $(p<0.01)$.

Figure $4 \mathrm{~d}-\mathrm{f}$ shows the annual changes in the three basins. The maximum surplus of terrestrial water storage change for the two data products of the Amu Darya river basin and Syr Darya river basin appeared in April, while the maximum loss appeared in October. The annual variation of the Balkhash lake basin was slightly different from that of the other two basins; the calculations resulting from CSR-M and JPL-M were not completely consistent. The maximum annual variation surplus calculated by CSR-M was in April, while the maximum annual variation surplus calculated by JPL-M was in March, and the maximum loss was concentrated in October. On the whole, the annual variation of terrestrial water storage in the three basins displayed the maximum surplus in spring (March to May) and the maximum deficit in autumn (September to November).

\subsubsection{Spatial Variations in Terrestrial Water Storage}

In order to calculate the spatial changes in terrestrial water storage, the spatial distribution and spatial change trend of land water storage in the study area, from 2002 to 2016, were calculated. According to Figure 5a,b, the maximum surplus of terrestrial water storage retrieved by CSR-M and JPL-M was concentrated in the north and northwest of the Balkhash lake basin, with a surplus of $2.53 \sim 12.42 \mathrm{~mm}$ and 13.03 25.99 mm, respectively. The largest losses were $-144.83 \sim-35.86 \mathrm{~mm}$ in the eastern part of the Balkhash lake basin 
and $-61.83 \sim-55.44 \mathrm{~mm}$ in the northwestern part of the Amu Darya river basin, respectively. The inversion results of the CSR-M and JPL-M were consistent on the whole, but there were still slight differences in the middle part of the Amu Darya river basin and the eastern part of the Syr Darya river basin. The surplus of terrestrial water storage retrieved by CSR-M was 0 2.53 $\mathrm{mm}$ in the middle of the Amu Darya river basin, and the surplus area was small. The surplus area of JPL-M in the middle of the Amu Darya river basin was large, and the surplus amount was different near different irrigation areas. The maximum surplus amount of terrestrial water storage in Turkmenistan was $13.03 \sim 25.99 \mathrm{~mm}$. The surplus of terrestrial water stored at the border with Uzbekistan was $5.33 \sim 13.03 \mathrm{~mm}$, and the surplus in central Uzbekistan was at the minimum, at $0 \sim 5.33 \mathrm{~mm}$. The CSR-M inversion resulted in the eastern part of the Syr Darya river basin, showing a loss of $-13.40 \sim 7.7 \mathrm{~mm}$ of terrestrial water storage, while the JPL-M showed a surplus of $5.33 \sim 13.03 \mathrm{~mm}$.

As shown in Figure $5 c$,d, the spatial variation trend of the terrestrial water storage retrieved by CSR-M and JPL-M was consistent, showing an increasing trend in the north and northwest of the Balkhash lake basin, with an increasing rate of $0 \sim 1.41 \mathrm{~mm} /$ year and $0 \sim 8.90 \mathrm{~mm} /$ year $(p>0.05)$. Other regions showed a decreasing trend; the highest rates of decrease were mainly in the eastern part of the Balkhash lake basin and the western part of the Amu Darya river basin. The decreasing rates in the eastern part of the Balkhash lake basin were $-34.01 \sim-10.14 \mathrm{~mm} /$ year and $-32.23 \sim-11.16 \mathrm{~mm} /$ year $(p<0.001)$, respectively. The decline rates in the lower reaches of the Amu Darya river basin were $-20.59 \sim-6.94 \mathrm{~mm} /$ year and $-32.23 \sim-11.16 \mathrm{~mm} /$ year $(p<0.001)$, respectively.
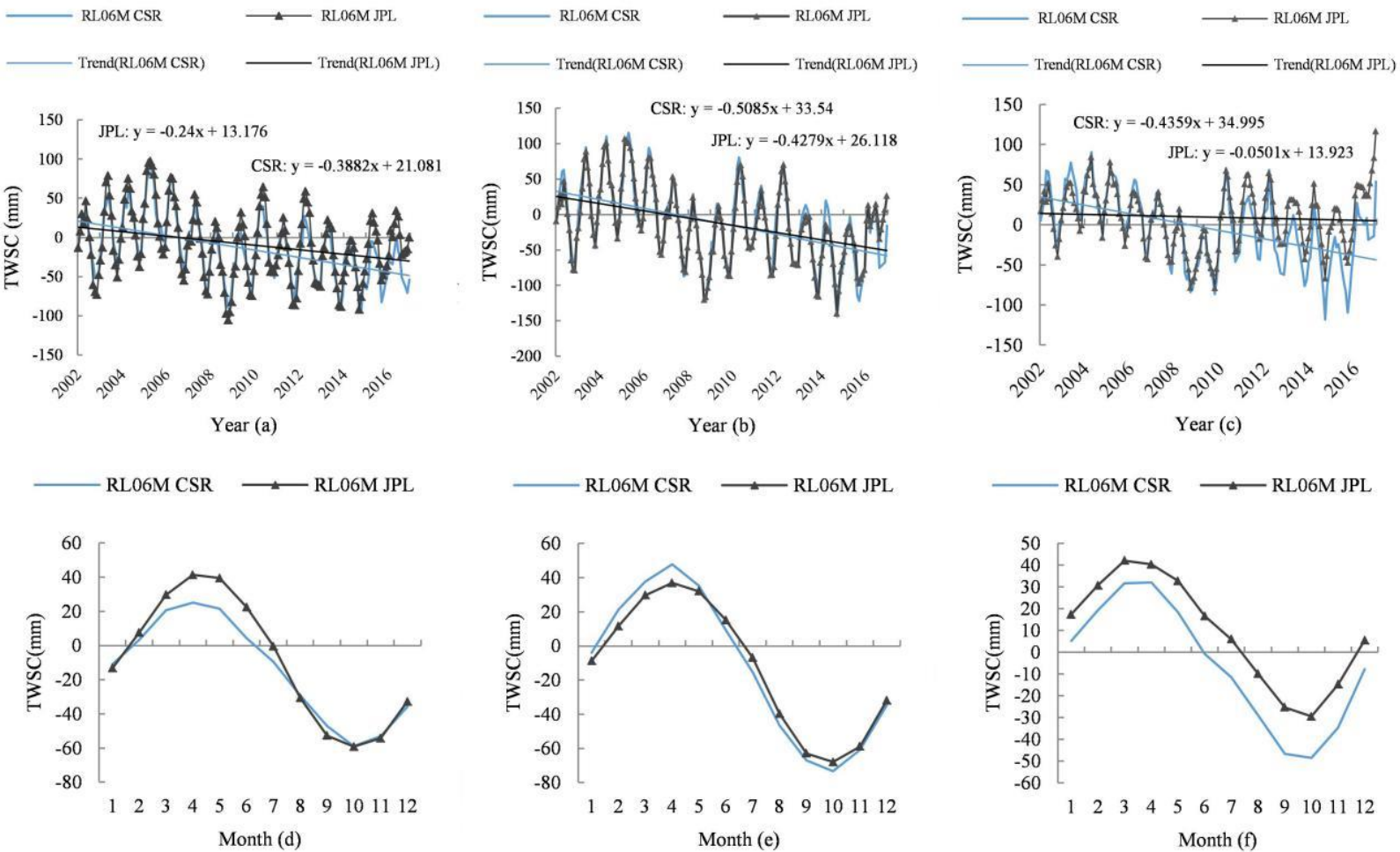

Figure 4. Time variation of the TWSC. $(\mathbf{a}-\mathbf{c})$ refer to the inter-annual variation of TWSC in the Amu Darya river basin, Syr Darya river basin and Balkhash lake basin, respectively, while (d-f) refer to the seasonal variation of TWSC in the Amu Darya river basin, Syr Darya river basin and Balkhash lake basin, respectively. 

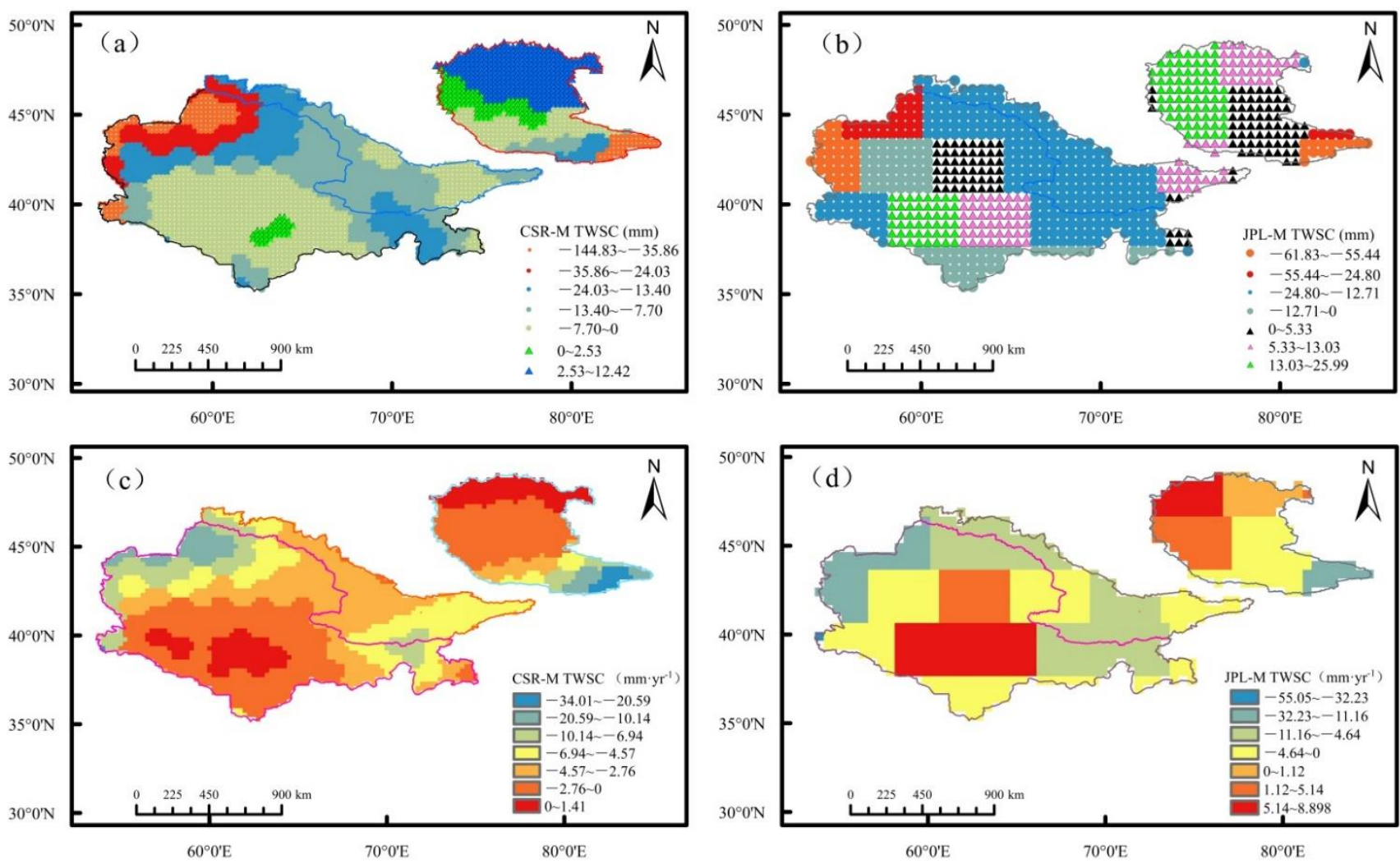

Figure 5. Spatial distribution of the TWSC retrieved by (a) CSR-M and (b) JPL-M; spatial trend analysis of the TWSC retrieved by (c) CSR-M and (d) JPL-M.

\subsection{Analysis of Dynamic Change in Groundwater Storage}

\subsubsection{Time Variation in Groundwater Storage}

Based on the above method, the interannual variation and annual variation of groundwater storage in the Amu Darya river basin, Syr Darya river basin and Balkhash lake basin were calculated. The groundwater storage in the Amu Darya river basin showed a decreasing trend during the study period, and the decreasing rates of JPL-M and CSR-M were $-2.17 \mathrm{~mm} /$ year and $-3.90 \mathrm{~mm} /$ year, respectively $(p<0.05)$. The fluctuation corresponded roughly to a cyclical change, first rising, then falling, then rising, etc.; during the whole research period, the node of rising or falling was mostly in June or July. As a sub-basin of the Aral Sea basin, the Syr Darya river basin had a more obvious decline than the Amu Darya river basin, and the fluctuation and periodicity of JPL-M and CSR-M were more consistent; their decline rates were $-3.72 \mathrm{~mm} /$ year and $-4.96 \mathrm{~mm} /$ year $(p<0.05)$, respectively. The groundwater storage of the two groups in the Balkhash lake basin showed a significant difference in their range of decrease, the decreasing rates being $-1.74 \mathrm{~mm} /$ year and $-3.36 \mathrm{~mm} /$ year, respectively $(p<0.05)$. The change characteristics of the three basins all indicate that the decline in groundwater storage in CSR-M was greater than that in JPL-M (Figure 6a-c). 

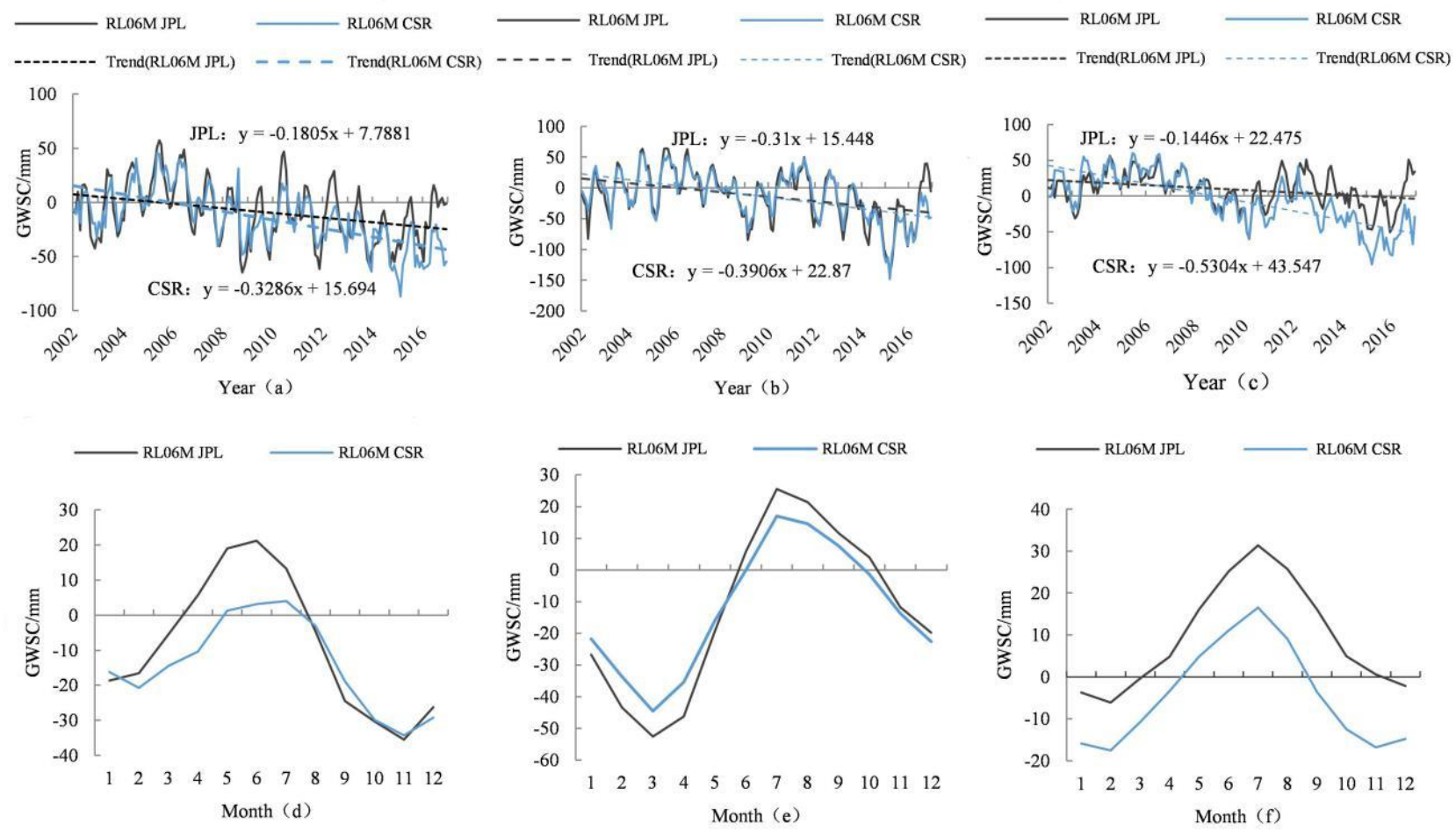

Figure 6. Time variation of the GWSC. $(\mathbf{a}-\mathbf{c})$ refer to the inter-annual variation of GWSC in the Amu Darya river basin, Syr Darya river basin and Balkhash lake basin, respectively, while (d-f) refer to the seasonal variation of GWSC in the Amu Darya river basin, Syr Darya river basin and Balkhash lake basin, respectively.

From the perspective of annual variation, the inversion results of JPL-M in the Amu Darya river basin show that the groundwater storage was in surplus from May to August, the maximum groundwater storage $(21.20 \mathrm{~mm})$ appeared in June, the groundwater storage was in deficit from September to April of the following year and reached the minimum value $(-35.48 \mathrm{~mm})$ in November. Inverting the results of CSR-M shows a continuous increase from February to July, reaching the maximum surplus of $4.05 \mathrm{~mm}$ in July, and a sustained loss from July to November, reaching the maximum loss of $-34.27 \mathrm{~mm}$ in November. In the Syr Darya river basin, both March and July were the nodes of the annual change trend; that is, the groundwater storage in the Syr Darya river basin reached the minimum value in March (about $-52.53 \mathrm{~mm}$ and $-44.52 \mathrm{~mm}$ ) and reached the maximum value in July (about $25.51 \mathrm{~mm}$ and $16.99 \mathrm{~mm}$ ). The groundwater storage was in surplus from June to October, and in deficit from November to May of the following year. Compared with the Amu Darya river basin, the surplus of groundwater storage in the Syr Darya river basin lagged by one month. During the annual variation process of the Balkhash lake basin, the surplus of JPL-M groundwater storage was concentrated from April to November, and the deficit was concentrated from December to February of the following year. The surplus of CSR-M groundwater storage was greatest from May to August, and the deficit was greatest from September to April of the next year. The maximum earnings were greatest in July $(31.42 \mathrm{~mm}, 16.58 \mathrm{~mm})$, and the maximum losses were greatest in February $(-6.10 \mathrm{~mm}$, $-17.5 \mathrm{~mm}$ ). The earnings cycle of JPL-M was longer than that of CSR-M (Figure 6d-f).

\subsubsection{Spatial Variations in Groundwater Storage}

As shown in Figure 7, on the whole, the decreasing trend of groundwater storage in the whole study area was greater than the increasing trend. The CSR-M inversion results show that the surplus area of groundwater storage was concentrated in the central and southern part of the Amu Darya river basin and scattered areas in the northwest of the Balkhash lake basin, with a rate of increase of about $0.03 \sim 3.88 \mathrm{~mm} /$ year $(p>0.05)$. The maximum loss was concentrated in the eastern scattered area of the Balkhash lake basin, with a range 
of $-26.84 \sim-20.09 \mathrm{~mm} /$ year $(p<0.001)$. As a whole, the groundwater storage in the Syr Darya river basin showed a decreasing trend at different rates, and the decreasing range was least at the junction of the middle and lower reaches $(p<0.01)$. The spatial variation of JPL-M is as follows: the groundwater storage increased at a rate of $0 \sim 4.20 \mathrm{~mm} /$ year in the northwest of the Balkhash lake basin $(p>0.05)$, and the most obvious decreasing trend was $-31.87 \mathrm{~mm} /$ year $-20.6 \mathrm{~mm} /$ year in the east $(p<0.001)$. The groundwater storage in the eastern part of the Syr Darya river basin increased at a rate of $0 \sim 16.04 \mathrm{~mm} /$ year, decreased at a rate of $-5.00 \sim-1.81 \mathrm{~mm} /$ year and $-9.70 \sim-5.00 \mathrm{~mm} /$ year in the middle reaches and the lower reaches, respectively, and the decreasing rates increased from the middle reaches to the lower reaches $(p<0.01)$. The groundwater storage in the middle and southern parts of the Amu river basin increased, and the increase rate was 4.20 16.04 mm/year $(p>0.05)$ in the irrigation area near the lower reaches. The groundwater storage in the western part of the Amu Darya river basin decreased at the rate of $-20.60 \sim-9.70 \mathrm{~mm} /$ year $(p<0.001)$. The differences between CSR-M and JPL-M data were mainly concentrated in the Balkhash lake basin, and the increasing area of JPL-M in the northwest of the Balkhash lake basin was larger than that of CSR-M. In the upper reaches of the Syr Darya river basin, JPL-M showed an increasing trend in groundwater storage, while CSR-M showed a decreasing trend.
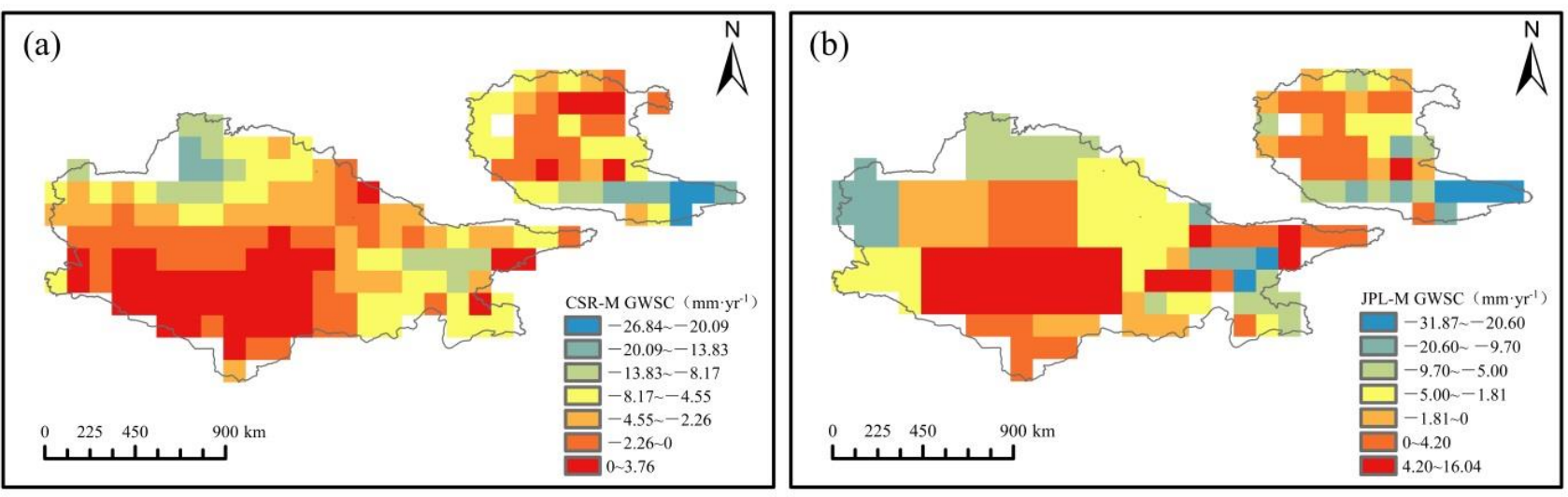

Figure 7. Spatial variations of the GWSC which retrieved by (a) CSR-M, and (b) JPL-M.

\subsection{Impact of Changing Environment Factors on the TWSC and the GWSC in Three Typical River Basins}

3.3.1. Sensitivity of the TWSC and GWSC in Typical River (Lake) Basins to Climatic Factors

For the closed inland lake basin, precipitation, snowmelt and glacier melt are the main sources of water, and temperature affects the conversion and dissipation of water resources by affecting snowmelt, ice melt and evapotranspiration. As shown in Figure 8, the annual precipitation in the Amu Darya river basin decreased at a rate of $-0.71 \mathrm{~mm} /$ year. The maximum annual precipitation of about $261.28 \mathrm{~mm}$ was found in 2003; the minimum annual precipitation was found in 2008, with a value of $151.62 \mathrm{~mm}$. The range of variation of precipitation in the Syr Darya river basin was greater than that in the Amu Darya river basin, and the significant decreasing trend of precipitation in the last 15 years was $-2.59 \mathrm{~mm} /$ year. In the Syr Darya river basin, the maximum and minimum annual precipitation values were $490.13 \mathrm{~mm}$ and $283.87 \mathrm{~mm}$, respectively. The annual average temperature in the Amu Darya river basin and the Syr Darya river basin increased slightly at rates of $0.008^{\circ} \mathrm{C} /$ year and $0.002{ }^{\circ} \mathrm{C} /$ year, respectively. The highest annual average temperatures were $14.05{ }^{\circ} \mathrm{C}$ in the Amu Darya river basin and $9.92^{\circ} \mathrm{C}$ in the Syr Darya river basin in 2016, respectively. The lowest annual average temperature was $12.61{ }^{\circ} \mathrm{C}$ in the Amu Darya river basin and $8.31^{\circ} \mathrm{C}$ in the Syr Darya river basin in 2014, respectively. The variation trend of climate factors in the Balkhash lake basin was the opposite of those in the Amu Darya and Syr Darya river basins; that is, the precipitation in the Balkhash lake basin increased at a rate of $0.71 \mathrm{~mm}$ /year. The maximum annual precipitation was $375.27 \mathrm{~mm}$ in 2016, and 
the minimum was $205.66 \mathrm{~mm}$ in 2008 . The temperature decreased slightly, at a rate of $-0.009{ }^{\circ} \mathrm{C} /$ year, and the maximum and minimum values of temperature lagged 1 to 2 months behind those of other basins. The highest average temperature was about $7.27^{\circ} \mathrm{C}$ in 2015, and the lowest average temperature was about $5.49^{\circ} \mathrm{C}$ in 2012.
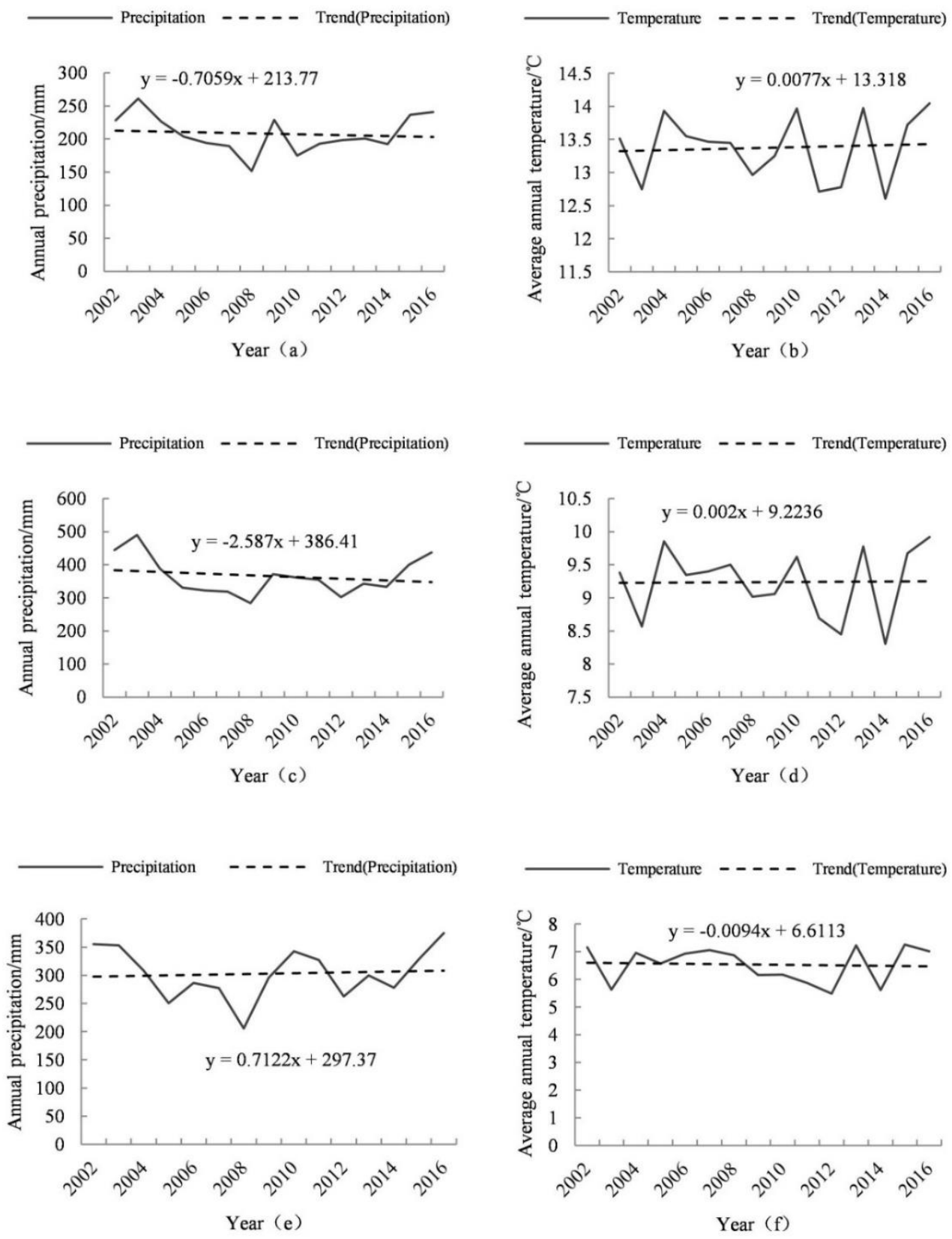

Figure 8. Temporal variation of climatic factors. $(\mathbf{a}, \mathbf{b})$ show the trends of precipitation and temperature, respectively, in the Amu Darya river basin; (c,d) show the trends of precipitation and temperature, respectively, in the Syr Darya river basin; $(\mathbf{e}, \mathbf{f})$ show the trends of precipitation and temperature, respectively, in the Balkhash lake basin.

In order to analyze the relationship between groundwater storage and climate change, a Pearson correlation analysis was used to calculate the correlation coefficient between water storage and temperature and precipitation. The results are shown in Figure $9 \mathrm{a}-\mathrm{d}$ : precipitation had a positive correlation with terrestrial water storage. Precipitation had a great influence on terrestrial water storage in the Balkhash lake basin, the upper reaches of the Syr Darya river basin, the eastern, central and southern parts of the Amu Darya river basin; and the maximum correlation coefficient reached $0.75(p<0.05)$. For the Syr Darya 
river basin, there was a very weak correlation at the middle reaches of the Syr Darya river basin. The correlation between the lower reaches of the Syr Darya River and the lower reaches of the Amu Darya river basin was different. The CSR-M showed a very weak negative correlation, while the JPL-M showed a very weak positive correlation $(p>0.05$; it is not significant at a $5 \%$ confidence interval). Compared with precipitation, the correlation coefficient between temperature and terrestrial water storage is smaller. There is a weak positive correlation between temperature and terrestrial water storage in the northern part of the Balkhash lake basin, and a weak negative correlation in the eastern part. The eastern part of the Syr Darya river basin is weakly negative and the other regions are weakly positive. The most significant effect of temperature on terrestrial water storage was found in the middle of the Amu Darya river basin, with a maximum correlation coefficient of 0.51 , and the negative correlation regions were concentrated in the east and south of the Amu Darya river basin ( $p>0.05$; it is not significant at a $5 \%$ confidence interval).

As shown in Figure $9 \mathrm{e}-\mathrm{h}$, the correlation between precipitation and temperature in the Balkhash lake basin and groundwater storage is extremely heterogeneous, and the results of the two sets of data show differences in correlation between precipitation and groundwater storage: specifically, the inversion results of JPL-M in the Balkhash lake basin show that precipitation is negatively correlated with groundwater storage in most areas, and precipitation is positively correlated with groundwater storage in the southwest ( $p>0.05$; it is not significant at a $5 \%$ confidence interval). The CSR-M inversion results show that there is a negative correlation between precipitation and groundwater storage in the northwest and north of the Balkhash lake basin $(p<0.05)$, and there is a weak positive correlation in the southeast ( $p>0.05$; it is not significant at a $5 \%$ confidence interval). On the whole, the two sets of data show a weak correlation between temperature and groundwater storage in the Balkhash lake basin.

Precipitation in the middle and upper reaches of the Syr Darya river basin has a greater influence on groundwater storage than on that in the lower reaches, and the correlation between temperature and groundwater storage is slightly different between the CSR-M and JPL-M results. The results from CSR-M show that there is a weak positive correlation between temperature and groundwater storage in the upper and middle reaches of the Syr Darya river basin, and a weak negative correlation between temperature and groundwater storage in the lower reaches ( $p>0.05$; it is not significant at a $5 \%$ confidence interval). The JPL-M results showed a negative correlation in the eastern part of the Syr Darya river basin $(p>0.05$; it is not significant at a $5 \%$ confidence interval); others were positive correlations. The maximum positive correlation was at the junction of the middle and lower reaches of the Syr Darya river basin, and the correlation coefficient was about $0.68(p<0.05)$. There is a strong correlation between precipitation and groundwater storage in the middle and south of the lower Amu Darya River basin, with a maximum correlation coefficient of 0.79 $(p<0.05)$. It can be judged that precipitation has a greater impact on the groundwater storage in the southern and middle reaches of the Amu Darya river basin. The influence of surface temperature on groundwater storage was concentrated in the lower reaches of the Amu Darya river basin, with a correlation coefficient of $0.68(p<0.05)$. In the correlation between climate factors and water storage, the correlation coefficient of JPL-M and climate factors was higher than that of CSR-M. 

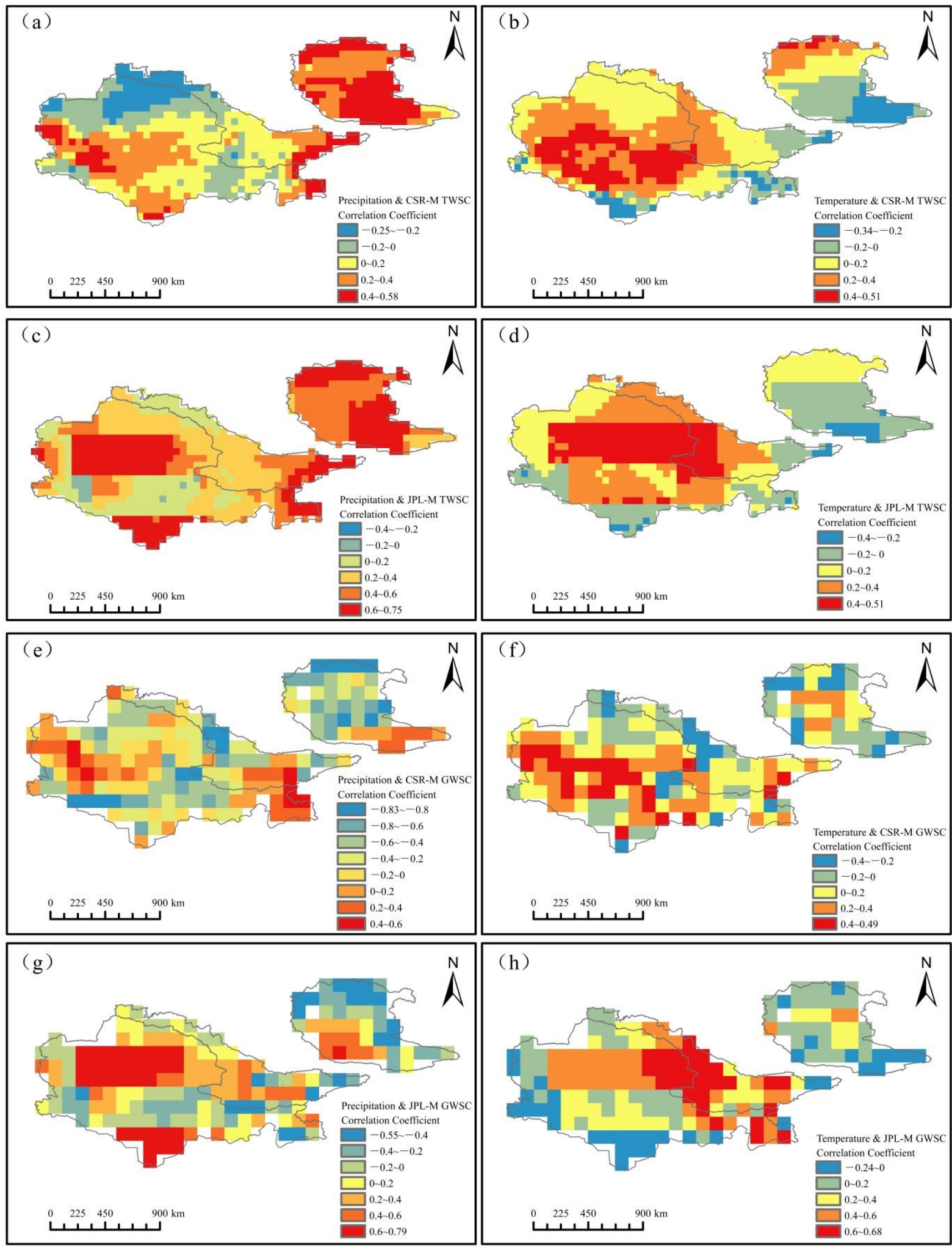

Figure 9. Correlation analysis between climate factors and water storage change. $(\mathbf{a}, \mathbf{c})$ show the correlation coefficients between precipitation and the TWSC which retrieved by CSR-M and JPL-M, respectively; (b,d) show the correlation coefficients between temperature and the TWSC which retrieved by CSR-M and JPL-M, respectively; (e,g) show the correlation coefficients between precipitation and the GWSC which retrieved by CSR-M and JPL-M, respectively; (f,h) show the correlation coefficients between temperature and the GWSC which retrieved by CSR-M and JPL-M, respectively. 


\subsubsection{Impact of Land Use Change on Water Storage in the Basin}

Water resource development and local management systems, as well as agricultural activities and changes in land-use area, have an impact on water storage. As shown in Table 2, compared with the year 2000, the area of cultivated land in each basin increased in 2015; the area of cultivated land in the Amu Darya river basin increased by $1.19 \times 10^{4} \mathrm{~km}^{2}$, in the Syr Darya river basin by $0.46 \times 10^{4} \mathrm{~km}^{2}$, and in the Balkhash lake basin by $0.3 \times 10^{4} \mathrm{~km}^{2}$. In addition to the Syr Darya river basin, which increased by $0.07 \times 10^{4} \mathrm{~km}^{2}$, the water area of the Amu Darya river basin and the Balkhash lake basin decreased by $-1.62 \times 10^{4} \mathrm{~km}^{2}$ and $-0.01 \times 10^{4} \mathrm{~km}^{2}$, respectively.

Table 2. Change in land use area in typical lake basins in 2000 and $2015\left(10^{4} \mathrm{~km}^{2}\right)$.

\begin{tabular}{|c|c|c|c|c|c|c|c|}
\hline & & $\begin{array}{l}\text { Cultivated } \\
\text { Land }\end{array}$ & Forest & Grassland & Bare Land & Water Area & $\begin{array}{l}\text { Urban Industrial and } \\
\text { Residential Land }\end{array}$ \\
\hline \multirow{3}{*}{$\begin{array}{l}\text { Amu Darya } \\
\text { river basin }\end{array}$} & 2000 & 7.94 & 1.70 & 12.49 & 80.61 & 4.07 & 1.14 \\
\hline & 2015 & 9.13 & 1.74 & 11.52 & 81.64 & 2.45 & 1.40 \\
\hline & Variation & 1.19 & 0.04 & -0.97 & 1.03 & -1.62 & 0.26 \\
\hline \multirow{3}{*}{$\begin{array}{l}\text { Syr Darya } \\
\text { river basin }\end{array}$} & 2000 & 4.98 & 1.12 & 10.37 & 13.72 & 1.28 & 0.80 \\
\hline & 2015 & 5.43 & 1.28 & 9.82 & 13.46 & 1.345 & 1.00 \\
\hline & Variation & 0.46 & 0.08 & -0.55 & -0.26 & 0.07 & 0.20 \\
\hline \multirow{3}{*}{$\begin{array}{l}\text { Balkhash } \\
\text { lake basin }\end{array}$} & 2000 & 1.97 & 1.02 & 12.48 & 18.31 & 2.00 & 0.15 \\
\hline & 2015 & 2.27 & 1.05 & 12.29 & 18.15 & 2.0 & 0.20 \\
\hline & Variation & 0.30 & 0.03 & -0.20 & -0.17 & -0.01 & 0.05 \\
\hline
\end{tabular}

The change in cultivated land area is the main alteration in the different categories. Especially in the Balkhash lake basin, the increase in the cultivated area accounted for $80.47 \%$ of the total increase in land-type area, and the increase in cultivated area in the Syr Darya river basin and the Amu Darya river basin accounted for $56.96 \%$ and $47.19 \%$, respectively. The change in water area was significant in the Amu Darya river basin, with the reduced water area accounting for $62.54 \%$ of the reduced land area. The decrease in water area in the Balkhash lake basin was less, with the reduced water area accounting for $0.13 \%$ of the reduced land area. The water area in the Syr Darya river basin increased slightly. The increased water area accounted for $8.58 \%$ of the increased land category area (Figure 10a).

The changes in land use and land cover type change the spatial and temporal allocation of water resources in the basin, and thus change the balance state of water resources in the whole system. The most direct change is the variation in evapotranspiration. With the increase in cultivated land area and temperature, evapotranspiration in the Amu Darya river basin, Syr Darya river basin and Balkhash lake basin showed an increasing trend, with increasing rates of $0.25 \times 10^{10} \mathrm{~m}^{3}, 0.09 \times 10^{10} \mathrm{~m}^{3}$ and $0.14 \times 10^{10} \mathrm{~m}^{3}$, respectively (Figure 10b-d).

As can be seen from Figure 11, evapotranspiration has a high correlation coefficient with terrestrial water storage and groundwater storage, which has a great impact on water storage. The region with the strongest correlation between evapotranspiration and terrestrial water storage was concentrated in the north of the Balkhash lake basin, and the maximum correlation coefficients of JPL-M and CSR-M were 0.93 and 0.81 , respectively $(p<0.01)$; the further north the location was, the stronger the correlation became. In the eastern mountainous area of the Syr Darya river basin, the correlation coefficient was about $0.6-0.8$ or $0.4-0.6$ ( $p>0.05)$; it is not significant at a $5 \%$ confidence interval); in the middle and lower reaches of the Amu Darya river basin, evapotranspiration was positively correlated with land water storage. The maximum negative correlation was found in the vicinity of the southern Aral Sea lake area. The stronger the evapotranspiration, the less the land water storage was in the vicinity of the Aral Sea lake area $(p<0.05)$. The terrestrial water storage in the middle and lower reaches of the Syr Darya river basin and 
the western part of the Amu Darya river basin was less affected by evapotranspiration, and the correlation degree was low.
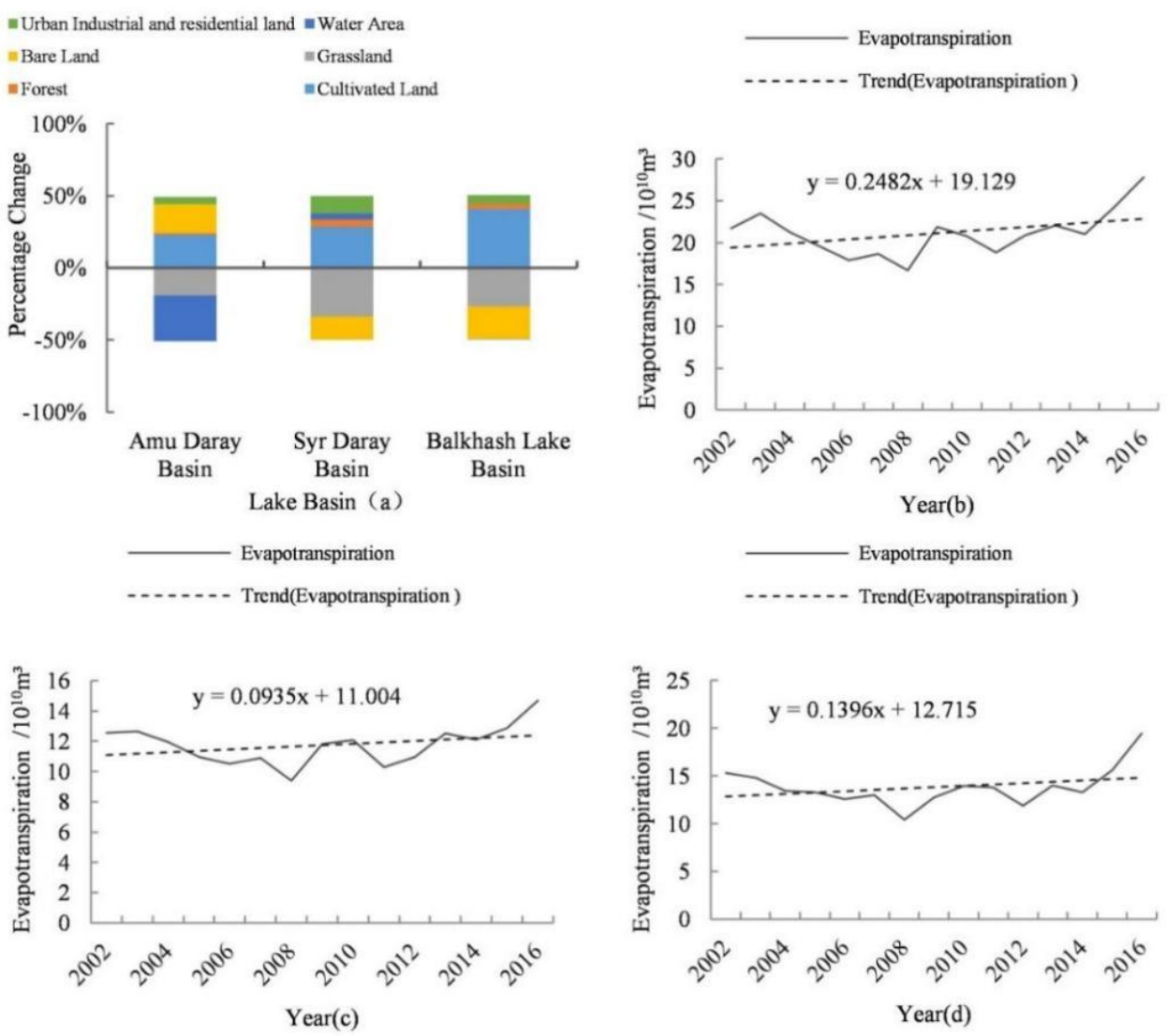

Figure 10. Change in land use and evapotranspiration. (a) represents the percentage of land use change in the three basins; (b-d) represent the annual evapotranspiration change in the Amu Darya river basin, the Syr Darya river basin and the Balkhash lake basin, respectively.

In the process of analyzing the correlation between evapotranspiration and groundwater storage, it was found that the results from JPL-M showed that the moderate correlation between evapotranspiration and groundwater storage was concentrated in the southwest part of the Balkhash lake basin, and the scattered areas in the north and south of the basin showed a moderate negative correlation. The results from CSR-M show that the negative correlation between evapotranspiration and groundwater storage was concentrated in the north of the Balkhash lake basin, while the positive correlation was concentrated in the southwest of the Balkhash lake basin. Moreover, the influence of evapotranspiration on terrestrial water storage in the Balkhash lake basin was greater than the influence on groundwater storage. As shown in Figure 11c,d, the correlation between evapotranspiration and the change in groundwater storage in the JPL-M data is not strong, mostly showing a weak correlation or no correlation ( $p>0.05$; it is not significant at a $5 \%$ confidence interval), but in the results from CSR-M, there was a strong negative correlation $(p<0.05)$. The correlation between groundwater storage and evapotranspiration in the Amu Darya river basin shows regional characteristics. There was a weak correlation between evapotranspiration and groundwater storage in the eastern mountains of the Amu Darya river basin ( $p>0.05$; it is not significant at a $5 \%$ confidence interval), the evapotranspiration in the central area of the Amu Darya river basin was weakly correlated with groundwater storage and the south-central level of evapotranspiration was weakly or moderately correlated with groundwater storage or strongly correlated with groundwater storage $(p<0.05)$. There was a weak correlation between evapotranspiration and groundwater storage in the western Amu Darya river basin ( $p>0.05$; it is not significant at a 5\% confidence interval), and a 
moderate negative correlation was concentrated in the northern part of the lower Amu Darya river basin $(p<0.05)$.
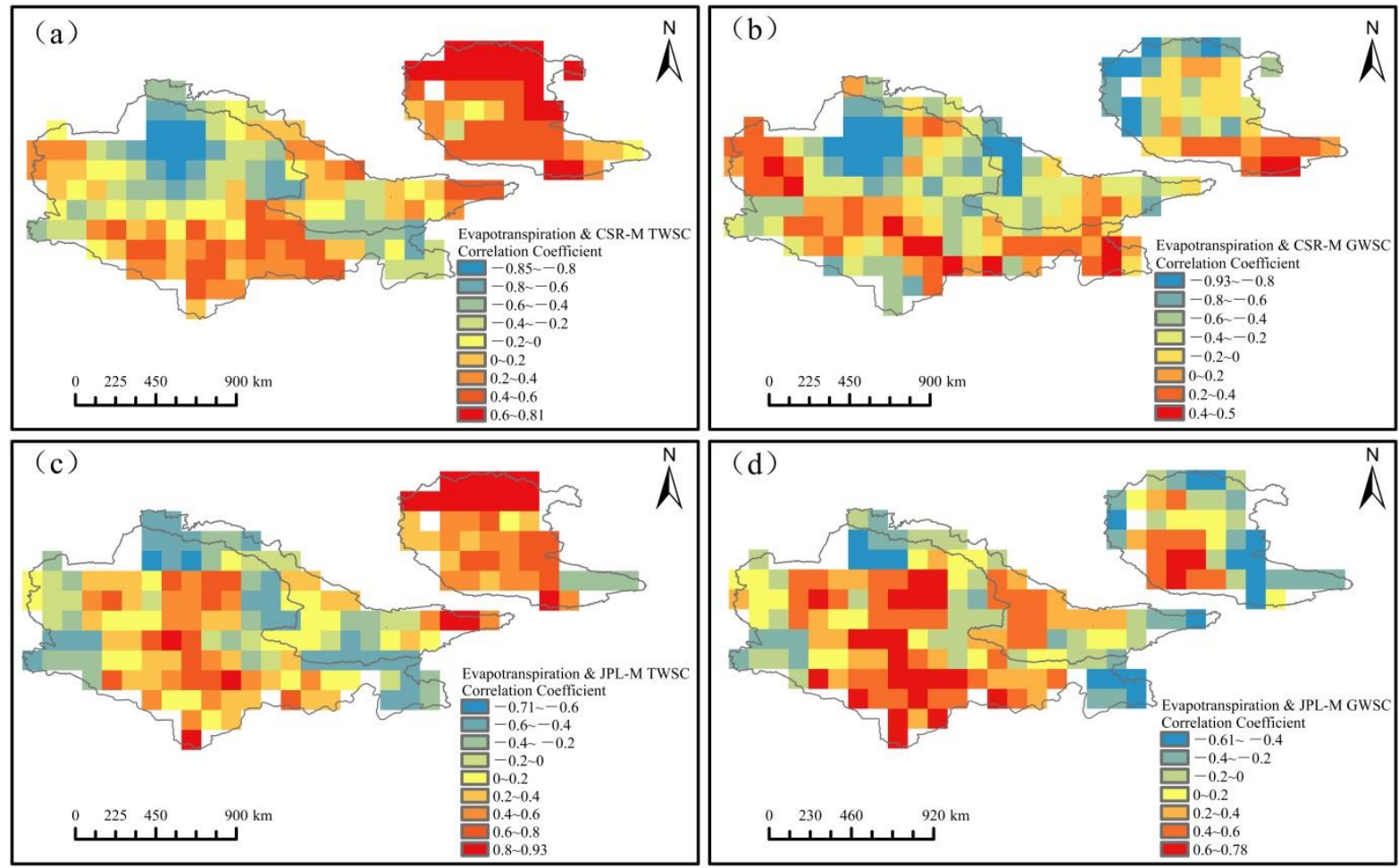

Figure 11. Correlation analysis between evapotranspiration and water storage change. $(\mathbf{a}, \mathbf{c})$ show the correlation coefficients between evapotranspiration and the TWSC retrieved by CSR-M and JPL-M, respectively; $(\mathbf{b}, \mathbf{d})$ show the correlation between evapotranspiration and the GWSC retrieved by CSR-M and JPL-M, respectively.

\section{Discussion}

The temporal and spatial changes in TWS and GWS in the typical basins of Central Asia in this study are basically consistent with previous related research [11-17]. However, most of the previous studies investigated the variation in TWS at regional and national scales, and the results presented differences due to the different time and spatial scales of data extraction. In general, the TWS in Central Asia has been decreasing since 2002. Among the typical basins, the Amu Darya river basin in the west of Central Asia has the largest reduction of TWS and GWS, and the Balkhash lake basin in the east has a relatively small reduction in TWS and GWS. The increase in TWS was mainly found in mountainous areas. Zhang et al. [12] and Yang et al. [11] indicated that the TWS in the western Tianshan Mountain increased from 2003 to 2013, which is highly related to the increase in winter precipitation in the mountainous region. We found that the TWS in the mountainous areas in the upper reaches of the Amu Darya River and Syr Darya River also showed an increasing trend, which may be related to the increase in glacier and snow storage caused by the rise in precipitation [13].

The decreasing trend of TWS is more significant in the middle and lower reaches of the inland river basin $[13,15]$. Due to the dramatic shrinkage of the Aral Sea in recent years, the tail area of the Amu Darya River is the region with the largest reduction of TWS in Central Asia. Hu et al. [15] indicated that agricultural irrigation in oases exacerbates the TWSA depletion, and lead to TWS being decreased in the irrigation area. According to the analysis found in this study, the TWS variation in the Syr Darya River Basin meets this situation. The increase in crop-planting area in the upper and lower reaches of the basin leads to an increase in evapotranspiration, while the change in cultivated land and water area in the middle reaches is very small, and the change of evapotranspiration may be more affected by climate factors. However, in the middle reaches of the Amu 
Darya River, the TWS series that was extracted based on the RL06 Mascon monthly data product presents a different trend, one in which both the TWS and GWS have increased slightly. This is caused by local agricultural development and changing irrigation patterns, mainly in Uzbekistan. Since 1970, the irrigated area of five countries in the Aral Sea basin has increased rapidly. After the disintegration of the Soviet Union in 1991, great changes have taken place in the water resources development, utilization and management systems of different countries. The intensity and speed of cultivated land reclamation have been greatly reduced compared with the previous period, mainly increasing slowly and decreasing slightly, but the agricultural water consumption, dominated by irrigation, is still large [37-39]. The area of cultivated land in the Amu Darya river from 2002 to 2015 showed an increasing trend, especially in the middle reaches of the Amu Darya river; the new cultivated land area from 2000 to 2015 was $7600 \mathrm{~km}^{2}$, which accounts for $64.11 \%$ of the total increase in cultivated land in the Amu Darya river basin. The increased area of the Amu Darya river basin is larger than that in the Syr Darya river basin and other regions of Central Asia [40]. Zmijewski et al. [17] stated that groundwater recharge has increased in the central parts of basins and near agricultural areas, most likely as a result of irrigation losses to groundwater. Many of the irrigation systems are unlined, which allows the infiltration of some of the water through the bottoms of ditches and furrows. Reservoirs may also increase recharge levels, depending on the underlying geology. The observed groundwater level data also showed an increasing trend from 2000 to 2018 in the irrigation area that is located in the middle reaches of the Amu Darya river basin [41]. This is the result of water supply from irrigation and reservoir water exceeding the increase of evapotranspiration in this region. It can be seen that the impacts of climate change and human activities on the TWS have obvious spatial heterogeneity in the inland river basins of Central Asia.

The uncertainties of the TWS anomaly derived from GRACE are caused by two major factors of the filtering process and the coarse spatial resolution [15]. Previously, most studies were based on Release 5 (RL05) data products, in which the monthly TWS anomaly was retrieved using the spherical harmonic coefficient (SHC) method. Several studies have shown that compared with the SHC method, the solution of the Mascon model can retain more effective signals and improve the accuracy of inversion results, and offer a higher correlation with the results of the GLDAS hydrological model [26]. However, due to different background models and data-processing strategies, the Mascon solutions released by the JPM and CSR still show deviations. The trends and magnitude of TWS and GWS, based on the JPL-M and CSR-M, were relatively consistent in the Amu Darya river basin and Syr Darya river basin. In the Balkhash lake basin, the TWSC derived from JPM and CSR shows a decreasing trend, while the TWSC derived from GLDAS-Noah presents a slight decrease from 2002 to 2016; however, the values of the four evaluation metrics were within acceptable ranges. The uncertainties may also come from the GLDAS dataset, due to different land surface models and resolutions; the initial conditions, input datasets, and model structure contribute to the large-scale uncertainties of TWSC [42,43]. The use of ensemble data that include multiple models of GLDAS would effectively reduce uncertainty in future work.

\section{Conclusions}

In this study, we used the RL06 Mascon datasets from CSR and JPL to invert the change in terrestrial water storage in three typical inland river basins of Central Asia, including the Amu Darya river basin, Syr Darya river basin and Balkhash lake basin, from 2002 to 2016. Combined with the GLDAS-Noah hydrological model, we estimated the temporal and spatial changes in groundwater storage. Based on meteorological factors and land-use data, the impact of climate change and human activities on terrestrial water and groundwater storage were discussed. The following conclusions were drawn:

(1) From the perspective of interannual variation, the terrestrial water storage inverted by CSR and JPL decreased at the rates of $-4.66 \mathrm{~mm}$ /year and $-2.88 \mathrm{~mm}$ /year, 
respectively, in the Amu Darya river basin; at the rates of $-6.10 \mathrm{~mm} /$ year and $-5.13 \mathrm{~mm} /$ year, respectively, in the Syr Darya river basin; and at the rates of $-5.23 \mathrm{~mm} /$ year and $-0.60 \mathrm{~mm} /$ year, respectively, in the Balkhash lake basin. The annual change in terrestrial water storage in the three basins met the characteristics of maximum surplus in spring (March to May) and maximum deficit in autumn (September to November). From the spatial perspective, the maximum surplus of CSR-M and JPL-M inversion was concentrated in the north and northwest of the Balkhash lake basin, with a surplus of $2.53 \sim 12.42 \mathrm{~mm}$ and $13.03 \sim 25.99 \mathrm{~mm}$, respectively. The largest loss was $-144.83 \sim-35.86 \mathrm{~mm}$ in the eastern part of the Balkhash lake basin and $-61.83 \sim-55.44 \mathrm{~mm}$ in the northwestern part of the Amu Darya river basin, respectively.

(2) The estimated decreasing rates of JPL-M and CSR-M groundwater storage in the Amu Darya river basin were $-2.17 \mathrm{~mm} /$ year and $-3.90 \mathrm{~mm} /$ year, respectively. The decreasing rates of groundwater storage in the Syr Darya river basin were $-3.72 \mathrm{~mm} /$ year and $-4.96 \mathrm{~mm} /$ year, respectively. The groundwater storage of the two groups in the Balkhash lake basin showed a large difference in the decreasing range, with decreasing rates of $-1.74 \mathrm{~mm} /$ year and $-3.36 \mathrm{~mm} /$ year, respectively. In terms of spatial variation, the surplus areas of groundwater storage were concentrated in the central and southern part of the Amu Darya river basin and scattered areas in the northwest of the Balkhash lake basin. The groundwater storage in the Syr Darya river basin showed a decreasing trend at different rates; the decreasing range was least at the boundary of the middle and lower reaches. The difference between CSR-M and JPL-M was mainly concentrated in the Balkhash lake basin, and the area with an increasing trend in the northwest of the Balkhash lake basin, as estimated by JPL-M, was bigger than that estimated by CSR-M. In the upper reaches of the Syr Darya river basin, the groundwater storage identified by JPL-M showed an increasing trend, while the groundwater storage identified by CSR-M showed a decreasing trend.

(3) Compared with temperature and precipitation, evapotranspiration has a stronger correlation with the TWSC. In the case of the Amu Darya river basin, the water storage decrease mainly resulted from a decrease in precipitation and an increase in evapotranspiration, caused by rising temperatures. The reasons for the increase in water storage in the middle reaches may be that for a bigger cultivated land area, flood irrigation and reservoir storage increase the water income, which leads to an increase in regional water storage. In the results of JPL-M, the rising temperature in the upper reaches of the Syr Darya river basin led to the recharge of groundwater coming from the melting snow of mountain glaciers, which led to an increase in water storage. The frequent human activities and the increase in cultivated land area in the middle reaches of the Syr Darya river basin resulted in an increase in water resource consumption, which is the main reason for the decrease in terrestrial water and groundwater storage in the middle reaches of the Syr Darya river basin. The increase in evapotranspiration in the lower reaches of the Syr Darya river basin may be the cause of the decrease in terrestrial water and groundwater storage. The increase in precipitation, decrease in temperature and increase in farmland irrigation water in the northwest of the Balkhash lake basin led to the increase in land water storage in the northwest of the Balkhash lake basin, and the higher and lower terrain in the southeast and northwest of the Balkhash lake basin led to the surplus of groundwater storage in the northwest of the Balkhash lake basin. As for the whole Balkhash lake basin area, with an increase in precipitation and a decrease in temperature, the overall land water and groundwater reserves still showed a decreasing trend, which can be explained by the increase in evapotranspiration in the whole basin. 
Author Contributions: Y.H. and A.B. conceived and designed the framework of this study; R.Z. and H.Y. collected and processed the data; Y.L. analyzed the results and wrote the paper. All authors have read and agreed to the published version of the manuscript.

Funding: This research was funded by the Strategic Priority Research Program of the Chinese Academy of Sciences, Pan-Third Pole Environment Study for a Green Silk Road (Grant No. XDA20060301), the National Natural Science Foundation of China (Grant No. 42071245 and 42071049 ), K.C.Wong Education Foundation (GJTD-2020-14) and CAS Interdisciplinary Innovation Team (Grant No. JCTD2019-20).

Institutional Review Board Statement: Not applicable.

Informed Consent Statement: Not applicable.

Data Availability Statement: All data used in this study are openly available from sources quoted in the text.

Conflicts of Interest: The authors declare no conflict of interest.

\section{References}

1. Chen, Y.N.; Li, Z.; Fang, G.H.; Deng, H.J. Impact of climate change on water resources in the Tianshan Mountians, Central Asia. Acta Geogr. Sin. 2017, 72, 18-26.

2. Immerzeel, W.W.; Van Beek, L.P.H.; Bierkens, M.F.P. Climate change will affect the Asian Water Towers. Science 2010, 328, 1382-1385. [CrossRef]

3. Yang, X.P. Desertification and land use in the Arid areas of Central Asia. Quat. Sci. 1998, 2, 119-127.

4. $\quad$ Bai, J.; Shi, H.; Yu, Q.; Xie, Z.Y.; Li, L.H.; Luo, G.P.; Jin, N.; Li, J. Satellite-observed vegetation stability in response to changes in climate and total water storage in Central Asia. Sci. Total. Environ. 2019, 659, 862-871. [CrossRef] [PubMed]

5. Yang, S.T.; Yu, X.Y.; Ding, J.L.; Zhang, F.; Wang, F.; Ma, Y.G. A review of water issues research in Central Asia. Acta Geogr. Sin. 2017, 72, 79-93.

6. Han, Z.M.; Huang, S.Z.; Huang, Q.; Leng, G.Y.; Wang, H.; He, L.; Fang, W.; Li, P. Assessing GRACE-based terrestrial water storage anomalies dynamics at multi-timescales and their correlations with teleconnection factors in Yunnan Province, China. J. Hydrol. 2019, 574, 836-850. [CrossRef]

7. Guo, H.; Bao, A.M.; Ndayisaba, F.; Liu, T.; Jiapaer, G.; Tantawi, M.E.; Maeyer, P.D. Space-time characterization of drought events and their impacts on vegetation in Central Asia. J. Hydrol. 2018, 564, 1165-1178. [CrossRef]

8. Yao, J.Q.; Hu, W.F.; Chen, Y.N.; Huo, W.; Zhao, Y.; Mao, W.Y.; Yang, Q. Hydro-climatic changes and their impacts on vegetation in Xinjiang, Central Asia. Sci. Total. Environ. 2019, 660, 724-732. [CrossRef] [PubMed]

9. Seyoum, W.M. Characterizing water storage trends and regional climate influence using GRACE observation and satellite altimetry data in the Upper Blue Nile River Basin. J. Hydrol. 2018, 566, 274-284. [CrossRef]

10. Ramillien, G.; Frappart, F.; Cazenave, A.; Güntner, A. Time variations of land water storage from an inversion of 2 years of GRACE geoids. Earth Planet Sci. Lett. 2005, 235, 283-301. [CrossRef]

11. Yang, P.; Chen, Y.N. An analysis of terrestrial water storage variations from GRACE and GLDAS: The Tianshan Mountains and its adjacent areas, Central Asia. Quatern Int. 2015, 358, 106-112. [CrossRef]

12. Zhang, P.F. Temporal and Spatial Variation of Water Resource in Central Asian Inland. Doctoral Dissertation, University of Chinese Academy of Sciences, Beijing, China, 2017.

13. Hu, W.J.; Liu, H.L.; Bao, A.M.; EI-Tantawi, A.M. Influences of environmental changes on water storage variations in Central Asia. J. Geogr. Sci. 2018, 28, 985-1000. [CrossRef]

14. Deng, H.J.; Chen, Y.N. Influences of recent climate change and human activities on water storage variations in Central Asia. J. Hydrol. 2017, 544, 46-57. [CrossRef]

15. Hu, Z.Y.; Zhang, Z.Z.; Sang, Y.F.; Qian, J.; Feng, W.; Chen, X.; Zhou, Q.M. Temporal and spatial variations in the terrestrial water storage across Central Asia based on multiple satellite datasets and global hydrological models. J. Hydrol. 2021, $596,126013$. [CrossRef]

16. Yang, P.; Zhang, Y.Y.; Xia, J.; Sun, S.X. Identification of drought events in the major basins of Central Asia based on a combined climatological deviation index from GRACE measurements. Atmos. Res. 2020, 244, 105105. [CrossRef]

17. Zmijewski, K.; Becker, R. Estimating the Effects of Anthropogenic Modification on Water Balance in the Aral Sea Watershed Using GRACE: 2003-12. Earth Interact. 2014, 18, 1-16. [CrossRef]

18. Chen, T.; Bao, A.M.; Guo, H.; Zheng, G.X.; Yuan, Y.; Yu, T. Ecological vulnerability assessment for a transboundary basin in Central Asia and its spatiotemporal characteristics analysis: Taking Amu Darya River Basin as an example. J. Nat. Resour. 2019, 34, 2643-2657.

19. Tian, X.R.; Wang, G.Y.; Fan, Y.F. Aral Sea Basin Transboundary Water Cooperation: History, Present Situation and Reflections. J. Bound. Ocean. Stud. 2017, 2, 90-104. 
20. White, C.J.; Tanton, T.W.; Rycroft, D.W. The impact of climate change on the water resources of the Amu Darya Basin in Central Asia. Water Resour. Manag. 2017, 28, 5267-5281. [CrossRef]

21. Yao, J.Q.; Chen, Y.N. Trend analysis of temperature and precipitation in the Syr Darya Basin in Central Asia. Theor. Appl. Climatol. 2015, 120, 521-531. [CrossRef]

22. Zhou, W.J.; Xia, Z.Q.; Huang, F.; Chen, Q.C.; Zhao, P. Variation Characteristics of precipitation and its annual distribution in Balkhash Lake Basin. Water Resour. Power 2013, 31, 10-13.

23. Song, Y.G.; Shi, Z.T. Distribution and Compositions of Loess Sediments in Yili Basin, Central Asia. Sci. Geogr. Sin. 2010, 30, 267-272.

24. Xuekelaiti, B.; Long, A.H.; Deng, M.J.; Li, X.Q.; Kadeer, M. Disquisition for water resources development and utilization in middle-lower reaches of Balkhash Basin on Google Earth. Arid. Land Geogr. 2012, 35, 388-398.

25. Hao, J.S.; Zhang, F.Y.; Zhao, X.; Liu, Y.X. Spatiotemporal Chang of water storage and its influencing fators in the Ili-Balkhash Basin based on GRACE data. Remote Sens. Technol. Appl. 2017, 32, 883-892.

26. Wahr, J.; Zhong, S. Computations of the viscoelastic response of a 3-D compressible Earth to surface loading: An application to glacial isostatic adjustment in Antarctica and Canada. Geophys. J. Int. 2012, 192, 557-572.

27. Wang, L.S.; Chen, C.; Ma, X.; Fu, Z.Y.; Zheng, Y.H.; Peng, Z.R. Evaluation of GRACE mascon solutions using in-situ geodetic data: The case of hydrologic-induced crust displacement in the Yangtze River Basin. Sci. Total Environ. 2019, 707, 135606. [CrossRef] [PubMed]

28. Watkins, M.M.; Wiese, D.N.; Yuan, D.N.; Boening, C.; Landerer, F.W. Improved methods for observing Earth's time variable mass distribution with GRACE using spherical cap mascons. J. Geophys. Res. Soild Earth 2015, 120, 2648-2671. [CrossRef]

29. Li, A.H.; Cui, S.Y.; Wang, H.R.; Yu, C. Water storage changes in the middle reaches of the Yellow River Basin based on GRACE time variable gravitation model. J. Nat. Resour. 2017, 32, 461-473.

30. Seoane, L.; Ramillien, G.; Frappart, F.; Leblanc, M. Regional GRACE-based estimates of water mass variations over Australia: Validation and interpretation. Hydrol. Earth Syst. Sci. 2013, 17, 4925-4939. [CrossRef]

31. Thomas, A.C.; Reager, J.T.; Famiglietti, J.S.; Rodell, M. A GRACE-Based water storage deficit approach for hydrological drought characterization. Geophys. Res. Lett. 2014, 41, 1537-1545. [CrossRef]

32. Hamed, K.H. Trend detection in hydrologic data: The Mann-Kendall trend test under the scaling hypothesis. J. Hydrol. 2008, 349, 350-363. [CrossRef]

33. Yu, Y.S.; Chen, X.W. Division of variation process of high and low runoff based on Mann-Kendall method. J. Water Resour. Water Eng. 2013, 24, 60-63.

34. Cao, Y.P.; Nan, Z.T.; Cheng, G. GRACE Gravity Satellite Observations of Terrestrial Water Storage Changes for Drought Characterization in the Arid Land of Northwestern China. Remote Sens. 2015, 7, 1021-1047. [CrossRef]

35. Ehsan Bhuiyan, M.A.; Nikolopoulos, E.I.; Anagnostou, E.N.; Polcher, J.; Albergel, C.; Dutra, E.; Fink, G.; Martínez-de la Torre, A.; Munier, S. Assessment of precipitation error propagation in multi-model global water resource reanalysis. Hydrol. Earth Syst. Sci. 2019, 23, 1973-1994. [CrossRef]

36. Mei, Y.W.; Nikoloulos, E.; Anagnostous, E.; Borga, M. Evaluating satellite precipitation error propagation in runoff simulations of mountainous basins. J. Hydrometeorol. 2016, 17, 1407-1423. [CrossRef]

37. Zhou, Y.; Zhang, L.; Xiao, J.F.; Williams, C.A.; Vitkovskaya, I.; Bao, A.M. Spatiotemporal transition of institutional and socioeconomic impacts on vegetation productivity in Central Asia over last three decades. Sci. Total Environ. 2019, 658, 922-935. [CrossRef]

38. Mueller, L.; Suleimenov, M.; Karimov, A.; Qadir, M.; Saparov, A.; Balgabayev, N.; Helming, K.; Lischeid, G. Land and Water Resources of Central Asia, Their Utilization and Ecological Status; Springer International Publishing: New York, NY, USA, 2014. [CrossRef]

39. Ibrayev, T.; Badjanov, B.; Li, M. Long-Term Monitoring and Water Resource Management in the Republic of Kazakhstan; Springer International Publishing: New York, NY, USA, 2014. [CrossRef]

40. Ruan, H.W.; Yu, J.J. Changes in land cover and evapotranspiration in the five Central Asian countries from 1992 to 2015. Acta Geogr. Sin. 2019, 74, 1292-1304. (In Chinese)

41. Liu, Z.B.; Huang, Y.; Liu, T.; Li, J.L.; Xing, W.; Akmalov, S.; Peng, J.B.; Pan, X.H.; Guo, C.Y.; Duan, Y.C. Water balance analysis based on quantitative evapotranspiration (ET) inversion in NUKUS irrigation area, Lower Amu River Basin. Remote Sens. 2020, 12, 2317. [CrossRef]

42. Swenson, S.; Wahr, J. Post-processing removal of correlated errors in GRACE data. Geophys. Res. Lett. 2006, 33, L08402. [CrossRef]

43. Bhanja, S.N.; Mukherjee, A.; Saha, D.; Velicogna, I.; Famiglietti, J.S. Validation of GRACE based groundwater storage anomaly using in-situ groundwater level measurements in India. J. Hydrol. 2016, 543, 729-738. [CrossRef] 